\title{
The challenges and mental health issues of academic trainees
}

\section{[version 1; peer review: 2 approved]}

\author{
Renee Eleftheriades¹, Clare Fiala1, Maria D. Pasic (iD)2,3 \\ ${ }^{1}$ Department of Pathology and Laboratory Medicine, Mount Sinai Hospital, Toronto, ON, Canada \\ 2Laboratory Medicine and Pathobiology, St. Joseph's Health Centre, Toronto, ON, Canada \\ ${ }^{3}$ Department of Laboratory Medicine and Pathobiology, University of Toronto, Toronto, ON, Canada
}

\author{
V1 First published: 11 Feb 2020, 9:104 \\ https://doi.org/10.12688/f1000research.21066.1 \\ Latest published: 11 Feb 2020, 9:104 \\ https://doi.org/10.12688/f1000research.21066.1
}

\section{Abstract}

In the last decade, mental health issues have come to the foreground in academia. Literature surrounding student mental health continues to grow as universities try to implement wellness services and study the mental health of their students. Studies vary greatly in terms of measurement tools, timeframe, sample demographics, as well as the chosen threshold of symptom severity for diagnosis. This review attempts to summarize, contextualize and synthesize papers that pertain to the challenges faced by academic trainees at the undergraduate, graduate and post-graduate level.

The evidence for, and against, the common claim of increasing prevalence of mental health issues among students in recent years is discussed. While some studies support this claim, it is difficult to reach a definitive conclusion due to numerous confounding factors such as increased help-seeking behaviour, greater awareness of mental health issues and weak methodology. The prevalence of depression, anxiety, suicidal and self-injurious behaviour, distress and general mental illness diagnoses are discussed. Other issues known to influence mental health, such as sexual assault and bullying, are briefly addressed.

Finally, select studies on a few wellness strategies that may improve mental health of trainees, such as mindfulness, are summarised, along with diverse recommendations for individual students, universities, and academia as a whole.

\section{Keywords}

academic training, mental health, trainee challenges, anxiety, depression, graduate students, academic jobs, mindfulness

\section{Open Peer Review \\ Approval Status \\ 1 \\ version 1 \\ 11 Feb 2020

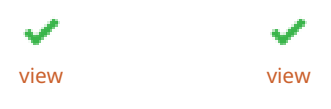 \\ 1. Teresa Evans ID, UT Health Science Center San Antonio, San Antonio, USA \\ 2. Leland Ackerson (ID), University of \\ Massachusetts at Lowell, Lowell, USA}

Any reports and responses or comments on the article can be found at the end of the article.

This article is included in the Research on

Research, Policy \& Culture gateway. 
Corresponding author: Maria D. Pasic (Maria.Pasic@unityhealth.to)

Author roles: Eleftheriades R: Conceptualization, Investigation, Visualization, Writing - Original Draft Preparation, Writing - Review \& Editing; Fiala C: Visualization, Writing - Review \& Editing; Pasic MD: Conceptualization, Data Curation, Formal Analysis, Methodology, Supervision, Visualization, Writing - Original Draft Preparation, Writing - Review \& Editing

Competing interests: No competing interests were disclosed.

Grant information: The author(s) declared that no grants were involved in supporting this work.

Copyright: $\odot 2020$ Eleftheriades R et al. This is an open access article distributed under the terms of the Creative Commons Attribution License, which permits unrestricted use, distribution, and reproduction in any medium, provided the original work is properly cited.

How to cite this article: Eleftheriades $\mathrm{R}$, Fiala $\mathrm{C}$ and Pasic MD. The challenges and mental health issues of academic trainees [version 1; peer review: 2 approved] F1000Research 2020, 9:104 https://doi.org/10.12688/f1000research.21066.1

First published: 11 Feb 2020, 9:104 https://doi.org/10.12688/f1000research.21066.1 


\section{Introduction}

In this review paper, we discuss the complex issues facing academic trainees and use many abbreviations summarized in Table 1 (references 1-14). Today, the pressure faced by university students at all levels may be greater than it has ever been in the past 25 years ${ }^{15}$. Increasing financial stressors since the 2007 recession are affecting undergraduates and graduates alike ${ }^{15-18}$. Students are increasingly concerned with getting a high-status job and earning a high income, and are consequently taking their academics more seriously ${ }^{15,19-21}$, resulting in increased feelings of academic pressure as early as high school ${ }^{15,19}$. This increased cultural focus on academia is reflected by the fast-paced growth in the number of $\mathrm{PhD}$ trainees, which is now outpacing the growth rate of the academic employment market ${ }^{22}$. As their numbers increase, graduate students face greater competition for a tightening pool of academic jobs, funding resources and mentorship ${ }^{16,23,24}$. These raised stakes underscore the pre-existing stresses and high competition inherent to academic culture ${ }^{25}$, resulting in intensely stressful conditions ${ }^{26}$. Thus, it is unsurprising that students have been repeatedly found to have worse overall mental health compared to the general population, characterized by elevated rates of depression, distress and other mental illnesses ${ }^{27-31}$.

Several studies have posited that the prevalence and severity of university student psychological issues is on the rise according to counselling centres, self-reported mental health data and symptom severity scales ${ }^{3,32,33}$, though the validity of these findings has been debated ${ }^{34,35}$. Still, even though the exact trends in psychopathology are difficult to verify due to confounding factors, mental health is increasingly being recognized as an important issue. The Cooperative Institutional Research Program at Higher Education Research Institute (CIRP) of the University of California at Los Angeles found that, for incoming freshmen, "student self-rating of emotional health was at an all-time low and feeling overwhelmed in high school had been increasing" in $2011^{15}$. In tandem with recent social movements to reduce stigma around mental illness and promote awareness, many universities are now trying to incorporate wellness into the student experience. This review will discuss some of the literature relevant to a variety of student mental health issues and some of the proposed solutions therein. Abbreviations used in this review can be found in Table 1 .

\section{Are student mental health issues increasing in prevalence and complexity?}

There is growing evidence suggesting that the prevalence and/or severity of university mental health issues has been increasing over the past half-century. Summarized in Table 2, this section will discuss some of this evidence, as well as its criticisms. Firstly, as discussed in the Introduction, the CIRP at the University of California, Los Angeles, asserted that freshman

Table 1. Abbreviations used in this review.

\begin{tabular}{|c|c|c|}
\hline Abbreviation & Description & $\begin{array}{l}\text { Reference } \\
\text { (if applicable) }\end{array}$ \\
\hline AUU & American Association of Universities & \\
\hline ACHA NCHA & American College Health Association National College Health Assessment & \\
\hline BDI & Beck Depression Inventory & 2 \\
\hline CBT & Cognitive Behavioural Therapy & 3 \\
\hline CES-D & Center for Epidemiological Studies Depression & 4 \\
\hline CIRP & Cooperative Institutional Research Program & \\
\hline CORE-OM & Clinical Outcomes in Routine Evaluation-Outcome Measure & 5 \\
\hline DASS-42 & 42-item Depression, Anxiety, and Stress Scale & 6 \\
\hline GAD-7-7-item & Generalized Anxiety Disorder scale & 7 \\
\hline GAIN-SS & Global Appraisal of Individual Needs-Short Screening & 8 \\
\hline GHQ-12 & 12-item General Health Questionnaire & 9 \\
\hline GYA & Global Young Academy & \\
\hline HERI & Higher Education Research Institute & \\
\hline K10 & 10-item Kessler scale & 10 \\
\hline MDI & Major Depression Inventory & 11 \\
\hline MEES & Mundane extreme environmental stress & 12 \\
\hline MMI & Mild-moderate mental illness & \\
\hline NSSI & Non-Suicidal Self Injury & \\
\hline OECD & Organisation for Economic Co-operation and Development & \\
\hline PHQ-9 & 9-item Patient Health Questionnaire & 14 \\
\hline SMI & Severe Mental IIIness & \\
\hline SCOFF & A screening tool for eating disorders & 1 \\
\hline RAINN & Rape, Abuse, and Incest National Network & \\
\hline
\end{tabular}


Table 2. Summary of the topics covered in this paper. Please refer to Table 1 for abbreviations.

\begin{tabular}{|l|l|l|}
\hline Topic & Description & Assessment scales \\
\hline Depression & $\begin{array}{l}\text { Depressive symptom scales assess feelings of sadness, hopelessness, self-blame, } \\
\text { emptiness, disturbances in sleeping and appetite and concentration difficulties. }\end{array}$ & $\begin{array}{l}\text { BDI, PHQ-9, CES-D, MDI, } \\
\text { DAS-42, Goldberg }\end{array}$ \\
\hline Anxiety & $\begin{array}{l}\text { Anxiety symptom scales assess feelings of nervousness, worry, restlessness, } \\
\text { dread, etc. }\end{array}$ & $\begin{array}{l}\text { PHQ-9/GAD-7, DAS-42, } \\
\text { Goldberg }\end{array}$ \\
\hline Distress & $\begin{array}{l}\text { Psychological distress is a general measure of negative feelings, stress, mood } \\
\text { dysphoria, and psychological strain. Distress is positively correlated to the } \\
\text { likelihood of developing a mental illness }{ }^{23} \text {. }\end{array}$ & $\begin{array}{l}\text { DAS-42, Trauma } \\
\text { Symptom Inventory, }\end{array}$ \\
\hline Suicidality & $\begin{array}{l}\text { Includes suicidal thoughts, consideration, ideation, planning, or attempts } \\
\text { GHQ-12 }\end{array}$ & $\begin{array}{l}\text { GAIN-SS, Meehan } \\
\text { Inventory }\end{array}$ \\
\hline
\end{tabular}

self-reported mental health is at an all-time low for the past 25 years, as a direct result of increasing economic pressures ${ }^{15}$. The study found that this deterioration in self-reported mental health coincides with an increase in student loan use and a decrease in financial independence due to decreasing job opportunities.

Twenge et al. ${ }^{33}$ performed a cross-temporal meta-analysis of self-reported student mental health between 1938 and 2007. The authors chose to do a cross-temporal analysis to avoid the issue of response bias which results from people with depression not living as long as the average population. They also controlled for each generation's propensity to lie and corrected their answers on psychopathology scales, adjusting for newer generations being more open to answering the survey honestly. Their assessment of mental health via the Minnesota Multiphasic Personality Inventory found that mental health worsened in each generation, including increased anxiety, depression, and dissatisfaction. These authors attribute this worsening to increased materialism and ambition. They comment that such ambition may be unrealistic, leading to eventual depression, and also that these goals may not be as fulfilling finding "meaning" in life and building interpersonal relationships.

Gallagher, in his National Survey of College Counselling Centers, reports that $94 \%$ of American college counselling centre directors agree that there is a continuously increasing number of students with severe psychological problems ${ }^{36}$. Almost $90 \%$ of directors reported an increase in anxiety disorders over the past 5 years, while $58 \%$ reported an increase in clinical depression. It is also worth noting that $69 \%$ "reported an increase in crises requiring immediate response", such as a student with a suicidal ideation.

It is entirely possible that this increase in students seeking counselling is due to the reduction of social stigma around mental health. Hunt and Eisenberg ${ }^{35}$ explore this possibility and find that this increased prevalence in reported problems does coincide with increases in help-seeking behaviour, but that it is possible that mental illness severity is indeed increasing in tandem.
Benton et $a .^{3}$ performed an analysis of the severity and frequency of the problems presented to campus therapists between 1988 and 2001, using the Case Descriptor List, a report filed by the therapist at the end of the client's case. They found a threefold increase in suicidal tendencies, a twofold increase in depression, and a fourfold increase in issues stemming from sexual assault, concluding that not only the prevalence, but also the severity, of student mental health problems were on the rise. Until 1994, relationship issues were the most common reason for seeking counselling, but thereafter, depression and anxiety took its place. However, they acknowledged that several studies using client self-report data or "objective" measurement scales (i.e. not dependent on the report of the client or psychologist) consistently find no such increase. This raises the possibility that, for unknown reasons, therapists perceive an increase in student issues that is not reflected by self-reports or other attempts based on objective measurements.

In fact, based on this possibility, there is a body of work disputing the claim that student mental health issues are increasing at all. Sharkin disputes the validity of using counselling practitioners' perceptions as evidence for an increase in mental health issues ${ }^{37}$. He also offers a critique on the aforementioned Benton study, firstly on the basis of its methods of measuring distress, which he feels are too vague to produce conclusive results, and secondly on its potential sampling bias, since it only examined students already receiving counselling ${ }^{34}$. However, it is important to note that Benton et al. did find a likely-genuine increase in students seeking counselling for career-planning issues. The authors believe this increase to be objectively genuine (rather than an artefact of therapists' perceptions) because the number of students seeking vocational counselling decreased upon the establishment of a careerdevelopment centre at the studied university, but then increased again later ${ }^{3}$. This increase in career concerns is consistent with that described by the $\mathrm{CIRP}^{15}$, Twenge et al. ${ }^{33}$, and Bishop ${ }^{19}$.

Costello and colleagues found no difference in depression levels for young persons over a 30-year span in a review of 26 studies, although cohorts were not specific to university students $^{38}$. 
Strepparava and colleagues performed a 5-year study of Italian students receiving counselling, but they did not find an increase in mental health issue severity or prevalence ${ }^{39}$. However, 5 years is a very short timeframe for assessing overarching trends in mental health issues ${ }^{37}$.

Cornish et al..$^{40}$ studied university students over a 6-8 year span and found no significant increase in mental health problems, and Berger et $a l .^{41}$ and Franke et al. ${ }^{42}$, actually found a decrease in mental health issue severity over time. However, the latter two authors were both studying German students, and attribute the decrease to positive changes in academic conditions that are specific to Germany only (for example, massive reduction in tuition). Furr et al. also found that depression rates decreased from $81 \%$ to $53 \%$ between 1987 and 200143. Pledge et al. acknowledge a large body of works that have found increases in mental health issues up to the 1980s, but the authors themselves did not find any difference between 1989 and 1995 . They hypothesize that mental health issues may have been increasing until the $1980 \mathrm{~s}$, but thereafter began to plateau ${ }^{44}$. Finally, in a systematic review of 24 studies, Ibrahim and colleagues found no trend of increasing prevalence of mental health problems between 1990 and $2010^{27}$.

Thus, the trend in student mental health issue prevalence is a controversial topic. While the above studies may not be reflective of a true increase in mental health issue prevalence among students, they reflect the importance of well-staffed and well-resourced university counselling centres and reveal that mental health and wellness are increasingly becoming important to students and universities.

\section{Depression}

Rates of depression reported among students vary greatly, depending on factors such as symptom scale, demographics and time period, as summarized in Table 3. This section will discuss various reports and contextualize their findings. The American College Health Association National College Health Assessment (ACHA NCHA) Fall $2018^{45}$ reported that $17.3 \%$ of respondents (a mixed sample of about three quarters undergraduates and one quarter graduates) had accessed professional services for depression in the past 12 months.

Systematic literature reviews have found massive ranges of depression incidence among students: Ibrahim et al. found a global range of $10-84.5 \%$ among undergraduates ${ }^{27}$ and Alfaris et al. found $8-70 \%{ }^{46}$ among Saudi Arabian health science students specifically. These ranges include the extremes of the most well-to-do universities in rich regions, to highly competitive conditions in impoverished regions. The weighted mean global rate of depression found by Ibrahim et al. was $30.6 \%$, which is closer to the following studies discussed in this review (though the mean for non-medical students only was slightly higher, $35.6 \%)$.

Independent studies surveying student symptoms using the PHQ-9 (Patient Health Questionnaire 9) for depression reported $13.8 \%{ }^{47}, 17.3 \%{ }^{17}, 15.4 \%^{48}$, and $7.9 \%^{49}$ among American, and in the last case, Australian, students. A well-known 2007 study on Emory University undergraduate students found the highest depression rates among the PHQ-9 studies included in this paper; they reported that $29.6 \%$ of the respondents had mild depression, $30.6 \%$ had moderate depression and $6.6 \%$ had

Table 3. Representative depression rates among undergraduate and other students. Please refer to Table 1 for abbreviations.

\begin{tabular}{|c|c|c|c|c|}
\hline Source & Measurement scale & Demographic & $\begin{array}{l}\text { Time range of } \\
\text { symptoms }\end{array}$ & Type and result \\
\hline $\mathrm{ACHA} \mathrm{NCHA}{ }^{45}$ & $\begin{array}{l}\text { Diagnosis or treatment by } \\
\text { professional }\end{array}$ & $\begin{array}{l}\text { Mixed: } ~ 85 \% \text { undergraduate; } \\
15 \% \text { graduate sample }\end{array}$ & Past 12 months & $17.3 \%$ \\
\hline Ibrahim et al. ${ }^{27}$ & $\begin{array}{l}\text { Various, including BDI, CES-D, } \\
\text { and PHQ-9 } \\
\text { (literature review) }\end{array}$ & Global, undergraduates & $\mathrm{N} / \mathrm{A}$ & $\begin{array}{l}10-84.5 \% \\
\text { Weighted mean: } 30.6 \%\end{array}$ \\
\hline Eisenberg et al. ${ }^{17}$ & PHQ-9 & $\begin{array}{l}\text { Mixed: } 74 \% \text { undergraduate; } \\
26 \% \text { graduate sample }\end{array}$ & Past 2 weeks & $\begin{array}{l}\text { Any, } 17.3 \% \text {; Major, } 9 \% \text {; } \\
\text { Mild, } 8 \%\end{array}$ \\
\hline Zivin et al. ${ }^{48}$ & PHQ-9 & American undergraduates & Past 2 weeks & Any, $13-15 \%$ \\
\hline Zivin et al. ${ }^{48}$ & PHQ-9 & American undergraduates & Past 4 weeks & Any, $15.4 \%$ \\
\hline Eisenberg et al. ${ }^{47}$ & PHQ-9 & $\begin{array}{l}\text { Undergraduates and } \\
\text { graduates }\end{array}$ & Past 4 weeks & U, $13.8 \% ;$ G $11.3 \%$ \\
\hline Farrer et al. ${ }^{49}$ & PHQ-9 & American undergraduates & Past 2 weeks & Major, $7.9 \%$ \\
\hline Garlow et al..$^{50}$ & PHQ-9 & $\begin{array}{l}\text { Emory University } \\
\text { undergraduates }\end{array}$ & Past 2 weeks & $\begin{array}{l}\text { Mild, } 29.6 \% \text {; Moderate, } \\
30.6 \% \text {; Severe, } 6.6 \%\end{array}$ \\
\hline Gress-Smith et al. ${ }^{51}$ & CES-D & American undergraduates & Past week & $\begin{array}{l}\text { Any, } 33.5 \% \text {; Moderate- } \\
\text { severe, 14.5\%; Mild, 19\% }\end{array}$ \\
\hline Bayram \& Bilgel 52 & DASS-42 & Turkish undergraduates & $\mathrm{N} / \mathrm{A}$ & Moderate, $27.1 \%$ \\
\hline Boujut et al. ${ }^{20}$ & Varying (literature review) & French students & Past 12 months & Any, 30\%; Major, 6\% \\
\hline Boujut et al.20 & $\mathrm{BDI}$ & French freshmen & Past week & Moderate or severe, $18 \%$ \\
\hline
\end{tabular}


severe depression ${ }^{50}$. A study using the CES-D (Centre for Epidemiologic Studies depression) scale found $14.5 \%$ for the rate of students with severe depression and an additional $19 \%$ with mild depression symptoms, totalling to $33.5 \%$ of students having any form of depression ${ }^{51}$. Using the DASS-42 (Depression, Anxiety and Stress) scale, Bayram and Bilgel found a rate of $27.1 \%$ for depression among Turkish university students $^{52}$. When Goldberg's Anxiety and Depression scale was used in a Spanish study, a much higher rate was found$55.6 \%{ }^{53}$. Boujut et al. report, in a review of French literature, depression rates of about $30 \%$, with $6 \%$ of students suffering from a major depressive episode. In their own study on university freshmen, they reported that $18 \%$ scored as moderately-to-severely depressed using the BDI (Beck Depression Inventory $)^{20}$

Many studies have also examined the prevalence of general feelings of depression or sadness among students, rather than depressive symptoms on a clinical scale. In a study on Australian first-year undergraduates, Hussain et al. found that $21.3 \%$ reported feeling "often/always unhappy", and $9 \%$ often/ always felt they had nothing to look forward to. However, this study also found that only $8 \%$ of first-year students had a diagnosis of either anxiety or depression ${ }^{54}$. It is worth noting that this study was performed in a rural area, so perhaps such settings have lower rates of mental health diagnoses for a number of possible reasons, including lower access to mental health services. Similarly, a UK study reported that $32 \%$ of undergraduate students felt "often or always" down/depressed in the past 4 weeks ${ }^{55}$. An American study found that $53 \%$ of students reported feelings of depression since having started college, but "depression" here was not given a standard definition by the authors but rather left up to the interpretation of the individual respondent. It is also worth noting that grades were the most common reason cited by students for their depressive feelings ${ }^{43}$.

\section{Anxiety}

The ACHA NCHA Fall 2018 survey reports that $22.1 \%$ of a mixed student sample (about three quarters undergraduates and one quarter graduates) had been seen by a professional for diagnosed anxiety in the past 12 months $^{45}$. In total, $62.3 \%$ reported having felt "overwhelming anxiety" in the past year, with $29.5 \%$ having felt that way in the past 2 weeks alone. The lowest rates of anxiety discussed in this paper were found by Zivin and colleagues, using the PHQ-9 (GAD-7) diagnosis scale: they reported rates of approximately $4 \%^{56}, 9.8 \%$ and $5-7 \%^{48}$. Interestingly, an Australian study using GAD-7, the extended and updated version of the PHQ-9, found a significantly higher rate of $17.5 \%$. The authors explain that this rate may be higher than that found by papers such as Zivin et al's because the extended and thorough nature of the GAD-7 makes it a more sensitive tool for detecting anxiety than the PHQ-9. Since this rate is much closer to that of students found to have been professionally diagnosed with anxiety by the AHCA NCHA, it is likely that the GAD-7 can identify students that the PHQ-9 would miss ${ }^{49}$.

Higher rates were found using other scales: two papers, one using the Goldberg's Anxiety and Depression scale and one using the DASS-42 scale, both found rates of $47 \%{ }^{52,53}$. Please see Table 4 for a summary of anxiety rates among students.

\section{Other mental health concerns}

Some literature does not specifically test for depression or anxiety but rather addresses the prevalence of general mental health concerns among subjects, as summarized in Table 5. In a selection of UK student surveys, $10-20 \%$ report having a mental health issue $e^{55,57-59}$. In a 2010 study of Australian undergraduates, $19.2 \%$ qualified as at-risk for a serious mental illness according to the K10 (Kessler) scale, and a further $64.7 \%$ show sub syndromic symptoms that classify them as at-risk of a mild/moderate mental illness. In a comparative age-matched

Table 4. Representative anxiety rates among undergraduate and other students. Please refer to Table 1 for abbreviations.

\begin{tabular}{|c|c|c|c|c|}
\hline Source & Measurement scale & Demographic & $\begin{array}{l}\text { Time range of } \\
\text { symptoms }\end{array}$ & Type and result \\
\hline $\mathrm{ACHA} \mathrm{NCHA}{ }^{45}$ & $\begin{array}{l}\text { Diagnosis or treatment } \\
\text { by professional }\end{array}$ & $\begin{array}{l}\text { Mixed: } \cup, \sim 85 \% \\
\text { undergraduate; } 15 \% \text { graduate }\end{array}$ & Past 12 months & $22.1 \%$ \\
\hline Eisenberg et al. ${ }^{56}$ & PHQ-9 & $\begin{array}{l}\text { Undergraduates and } \\
\text { graduates }\end{array}$ & Past 4 weeks & $\begin{array}{l}\text { Generalized anxiety, } 4.2 \% \text {; Panic } \\
\text { disorder, } 3.8 \%\end{array}$ \\
\hline Eisenberg et al. ${ }^{17}$ & PHQ-9 & $\begin{array}{l}\text { Mixed: } 67 \% \text { undergraduate; } \\
33 \% \text { graduate }\end{array}$ & Past 2 weeks & $\begin{array}{l}\text { Any, } 9.8 \% \text {; Panic disorder, } 4.1 \% \text {; } \\
\text { Generalized anxiety, } 7 \% \text {; Both, } \\
1.32 \%\end{array}$ \\
\hline Zivin et al. ${ }^{48}$ & PHQ-9 & $\begin{array}{l}\text { Mixed: } 48 \% \text { undergraduate, } \\
52 \% \text { graduate sample }\end{array}$ & Past 4 weeks & $\begin{array}{l}\text { Generalized anxiety, } 4.75 \% \text {; } \\
\text { Panic disorder, } 6.97 \%\end{array}$ \\
\hline Farrer et al. ${ }^{49}$ & GAD-7 & Australian undergraduates & Past 2 weeks & $\begin{array}{l}\text { Generalized anxiety disorder, } \\
17.5 \%\end{array}$ \\
\hline Galindo et al. ${ }^{53}$ & Goldberg & Spanish undergraduates & Past week & Any anxiety disorder, $47.1 \%$ \\
\hline Bayram \& Bilge ${ }^{52}$ & DASS-42 & Turkish undergraduates & Past week & Moderate to severe, $47.1 \%$ \\
\hline
\end{tabular}


Table 5. Mental health issues and psychological distress rates among undergraduate and general student samples. Please refer to Table 1 for abbreviations.

\begin{tabular}{|c|c|c|c|c|}
\hline Source & Measurement scale & Demographic & $\begin{array}{l}\text { Time range of } \\
\text { symptoms }\end{array}$ & Type and result \\
\hline Stallman ${ }^{31}$ & K10 scale & $\begin{array}{l}\text { Australian mixed: } 74 \% \\
\text { undergraduate; } 26 \% \text { graduate }\end{array}$ & Past 28 days & $\begin{array}{l}\text { SMI risk, } 19.2 \% \text {; MMI risk, } \\
64.7 \% \text {; No risk, } 16.1 \%\end{array}$ \\
\hline Zivin et al. ${ }^{48}$ & PHQ-9, SCOFF & American mixed & \multicolumn{2}{|c|}{$\begin{array}{l}\text { Depression, anxiety or eating disorder: } \\
\text { At any given timepoint: }>50 \% \\
\text { At both timepoints: }>33 \%\end{array}$} \\
\hline Bruffaerts et al. ${ }^{60}$ & GAIN-SS & Belgian freshmen & Past 12 months & $\begin{array}{l}\text { Any mental health problem, } \\
34.9 \%\end{array}$ \\
\hline Marcotte \& Lévesque ${ }^{25}$ & $\begin{array}{l}\text { Varying (literature } \\
\text { review) }\end{array}$ & European students & $\begin{array}{l}\text { Varying (literature } \\
\text { review) }\end{array}$ & Distress, $21-31 \%$ \\
\hline Bírá et al. ${ }^{61}$ & GHQ-12 & Hungarian health students & Past week & Distress, $19 \%$ \\
\hline Bayram \& Bilgel 52 & DASS-42 & Turkish undergraduates & Past week & Distress, $27 \%$ \\
\hline Adlaf et al. ${ }^{29}$ & GHQ-12 & Canadian undergraduates & $N / A$ & Elevated distress, $30 \%$ \\
\hline Marcotte \& Lévesque ${ }^{25}$ & $\begin{array}{l}\text { Varying (literature } \\
\text { review) }\end{array}$ & European students & $N / A$ & Psychological distress, $21-31 \%$ \\
\hline Bernaras et al. ${ }^{5}$ & Various, CORE-OM & Spanish students & $N / A$ & $\begin{array}{l}\text { Clinical cut-off for various } \\
\text { distress scales: } 47.4 \% ; 63.8 \%\end{array}$ \\
\hline Rosenthal \& Wilson ${ }^{62}$ & $\begin{array}{l}\text { Psychological } \\
\text { Distress Scale }\end{array}$ & American undergraduates & Past 2 months & $\begin{array}{l}\text { Clinically significant level of } \\
\text { distress, } 9 \%\end{array}$ \\
\hline Pereira et al..$^{57}$ & Diagnosis & UK students & Ever & Mental health issue, $20 \%$ \\
\hline Kerr 58 & Diagnosis & UK students & Ever & Mental health issue, $10 \%$ \\
\hline Neale et al..$^{55}$ & Self-report & UK students & Ever & Mental health issue, $12 \%$ \\
\hline
\end{tabular}

sample of the general population, only $3 \%$ classified as at-risk for a serious mental illness, supporting the conclusion that students have significantly higher rates of mental distress compared to the general population ${ }^{31}$.

Using the PHQ-9 and SCOFF eating disorder scale, Zivin et al. measured student mental health at the beginning and end of a two-year period. They found that, at either given time point, $35 \%$ of students had some probable mental health issue (depression, suicidal thoughts, self-harm, anxiety, or an eating disorder $)^{48}$. A very similar result was found by Bruffaerts et al., who measured freshman mental health with the WMH-ICS (World Mental Health International College Student) survey and found a prevalence rate of $34.9 \%$.

Many other studies also examine the prevalence of elevated or clinically significant distress among students. A brief review by Marcotte and Lévesque reports a range of $21-31 \%$ among European literature ${ }^{25}$. Two additional studies included in the present review have found rates that are in-line with this range using the GHQ-12 questionnaire: 19\% among Hungarian health students $^{61}$, and $30 \%$ among Canadian undergraduates ${ }^{29}$. Much higher rates were reported by studies using measures other than the GHQ-12, except for one that used the DASS-42 scale and found a rate of $27 \%$. Bernaras and colleagues reported that $47.4-62.8 \%$ of students were above the clinical cut-off in various measures of distress using the CORE-OM (Clinical Outcomes in Routine Evaluation-Outcome Measure) scale ${ }^{5}$.
Rosenthal and Wilson reported an even higher prevalence of $83 \%$ for "moderate-to-severe" distress among undergraduates, using the Dysphoria Domain of the Trauma Symptom Inventory and Psychological Distress Scale, although only 9\% of participants were classified as having clinically significant levels ${ }^{62}$. Finally, Hyun and colleagues reported that $44-45 \%$ of graduate students at University of California Berkeley selfreported a significant emotional or stress-related mental health concern $^{63,64}$.

\section{Suicidality and self-Injury}

Suicidality can be classified into consideration, ideation, plans and attempt. Table 6 provides an overview of the discussed studies. Some studies that have made an effort to distinguish serious thoughts from ideation include Eisenberg et al.' ${ }^{17}$ and Garlow et al.' 's ${ }^{50}$, which reported $6.3 \%$ and about $10 \%$ of students had such thoughts within the year the study was performed. Furthermore, Garlow also found that $19.2 \%$ of the $10 \%$ group were currently suicidal at the time of the study. Overall, $16.5 \%$ of the entire student population reported either a suicide attempt or non-suicidal self-injury incident at any point in their lives. They found that $12 \%$ of participants had reported a suicidal ideation in the past 12 months $^{45}, 4.2 \%$ reported ideation currently often or always $^{54}$, and $8.5 \%$ reported it since starting college ${ }^{43}$.

According to the ACHA NCHA, $2 \%$ of undergraduates have attempted suicide in the past 12 months ${ }^{45}$. Boujut et al. reported a range of $9-15 \%$ for suicidal ideation and $3-10 \%$ for suicide 
Table 6. Rates of suicidal and self-injurious behaviour among undergraduate and general student samples. Please refer to Table 1 for abbreviations.

\begin{tabular}{|c|c|c|c|c|}
\hline Source & Measurement scale & Demographic & $\begin{array}{l}\text { Time range of } \\
\text { symptoms }\end{array}$ & Type and result \\
\hline $\mathrm{ACHA} \mathrm{NCHA}{ }^{45}$ & $N / A$ & Undergraduates & Past 12 months & $\begin{array}{l}\text { Consideration, } 12 \% \text {; attempt, } 2 \% \text {; } \\
\text { NSSI, } 8.5 \%\end{array}$ \\
\hline Eisenberg et al. ${ }^{65}$ & $\begin{array}{l}\text { National Comorbidity } \\
\text { Survey Replication }\end{array}$ & American mixed & Past year & Serious thoughts, $6.3 \%$ \\
\hline Garlow et al..$^{50}$ & N/A & $\begin{array}{l}\text { Emory University } \\
\text { undergraduates }\end{array}$ & Past year & $\begin{array}{l}\text { Serious consideration, 10\%; } \\
\text { Attempt or NSSI, } 16.5 \%\end{array}$ \\
\hline Hussain et al. ${ }^{54}$ & $N / A$ & Australian freshmen & $N / A$ & $\begin{array}{l}\text { Ideation, at least sometimes, } 16.6 \% \text {; } \\
\text { Ideation, often/always, } 4.2 \% \text {; NSSI, } \\
3.7 \%\end{array}$ \\
\hline Furr et al. ${ }^{43}$ & N/A & $\begin{array}{l}\text { Almost purely } \\
\text { undergraduates (95\%), } \\
\text { American }\end{array}$ & During university & Ideation/thoughts, 8.5\% \\
\hline Boujut et al. ${ }^{20}$ & $N / A$ & French, varied ages & \multicolumn{2}{|c|}{$\begin{array}{l}\text { Varying (since starting studies or in past } 12 \text { months): } \\
\text { Ideation, } 9-15 \% \\
\text { Ever: Attempts, 3-10\% }\end{array}$} \\
\hline Boujut et al. ${ }^{20}$ & BDI & French freshmen & Past week & Plans, $4.3 \%$ \\
\hline
\end{tabular}

attempts among students ${ }^{20}$. In total, $4.3 \%$ of French freshmen reported having suicide plans. Hussain and colleagues further reported that $3.7 \%$ of first years surveyed had thoughts of selfharm (often or always), and that the percentage of students who had attempted self-harm at some point in their lives were $17 \%$ female and $11 \%$ male $^{54}$. For undergraduates, the rate of self-harm was $8.5 \%$ and the rate of suicide attempts was $2 \%$ in the past 12 months $^{45}$. For pure-graduate groups, the non-suicidal self-injury (NSSI) rate was $7.3 \%$ in the past 4 weeks ${ }^{66}$.

\section{Graduate students and post-doctorate challenges}

Graduate students face additional academic pressures, having to juggle a myriad of responsibilities, such as attending courses, managing their projects and writing papers. Many graduate students feel unsure about their future career paths and are afraid that they will not find a permanent position in academia ${ }^{67}$. Surveys find that graduate students' greatest concerns are their work-life balance, career security and success, financial security, and general uncertainty about their professional path $^{68,69}$.

As mentioned in the introduction, academic positions and funding are becoming increasingly more competitive ${ }^{23,24}$. The Organization for Economic Co-operation and Development reported that in the last 20 years, the number of young $\mathrm{PhDs}$ has doubled and academic positions did not keep pace with this rapid growth ${ }^{22,70-73}$. A 2014 report by the National Science Foundation found that employment across the science and engineering fields was the lowest in the past 15 years. For fields outside of science and engineering, employment was at the lowest in the past 20 years $^{73}$. An American study from 2014 estimated that, in engineering, there are only enough academic positions for $12.8 \%$ of $\mathrm{PhD}$ graduates ${ }^{71}$. Meanwhile, a Physics World article, using data from the Institute of Physics, estimated that just $1.7 \%$ of the UK postdocs in physics would go on to an academic position $^{74}$.

Graduate education is widely seen as a secure path to a highstatus job, but in reality about a third of graduates do not even believe that their $\mathrm{PhD}$ significantly improves their job prospects ${ }^{68}$. Many are afraid that they will not be able to find a job at the end of their studies, and this stress has been found to contribute to depressive feelings among graduate students ${ }^{75}$.

This increasing competition is also affecting grant funding: a report in the magazine Nature found that funding has not been increasing in pace with the growing number of PhDs. Major grant providers, such as the NIH and the European Research Council, now award grants to less than $20 \%$ of applicants, most of whom will be older scientists with more established careers rather than young investigators.

American funding success rates have more than halved since $1980^{67}$. A graduate student survey found that $50 \%$ of North American $\mathrm{PhD}$ trainees felt surprised by how difficult it was to secure funding ${ }^{67}$. The increased scarcity of funding and research resources is likely contributing to trainee mental health issues $^{23,30}$.

This high competition is usually explained by academia's emphasis on overwork. Especially in the sciences, academia has created a culture that venerates the idea of voluntary self-sacrifice for the collective advancement of humanity ${ }^{76,77}$. As a result, there is a persistent expectation on graduate students and young researchers in general, to overwork themselves ${ }^{24,30,78-82}$. Many academics "see suffering as a badge of honour", as University of Derby Psychotherapist Gareth Hughes explains in an interview with Nature $^{78}$. For many graduate students and other 
early-career researchers, it is not out of the ordinary to work 60-80 hours a week ${ }^{79,81,83}$, or at least be expected to ${ }^{84,85}$. One study on graduate students of economics, natural sciences and engineering found that about 55\% work 41-60 hours per week, and approximately another $25 \%$ work $61-80$ hours per week. According to this study, the majority of graduate students work far past the 9-5 hours expected in most jobs ${ }^{86}$. As Evans et al. put it "worklife balance is hard to attain in a culture where it is frowned upon to leave the laboratory before the sun goes down" ${ }^{30}$. Meanwhile, many graduate students struggle to make ends meet on their stipends alone, despite their long work hours ${ }^{69,87}$. The veneration of suffering in academia makes it difficult for graduate students to recognize their distress as a valid mental health issue rather than just the hardship expected in higher education ${ }^{88}$.

Consequently, several studies report that graduate students experience elevated stress levels, even compared to undergraduate students. The Gradresources survey found that $37 \%$ of graduate students experienced "more stress than they can handle" as a direct result of their studies, with a total of $45 \%$ reporting more stress than they can handle in general. A 2015 University of Arizona study found that $73 \%$ of graduate students reported greater than average stress, with $23 \%$ describing their stress level as "tremendous" $"$. In one survey of $\mathrm{PhD}$ students, 62\% reported worrying about their work even when they were not currently working ${ }^{86}$. The ACHA NCHA found that $61.4 \%$ of graduate students report greater than average stress, compared to $57 \%$ of undergraduates ${ }^{45}$.

Studies comparing graduate student mental health to the general population's found them to be at greater than two-to-six times the risk of depression and anxiety compared to the general population ${ }^{23,30,86}$. Specifically, Evans and colleagues found, using the PHQ-9 and GAD-7 scales, that graduate students experienced depression and anxiety at rates of $41 \%$ and $39 \%$, respectively. Comparatively, they reported rates of $6 \%$ for the general population in other GAD-7 studies ${ }^{30}$. Of course, the comparison studies are chosen on the basis of using the same measurement scale as the primary study, even though they may have been performed under different conditions. For example, the Evans study has been criticized for using a German sample as comparison rather than an American survey ${ }^{84}$. Levecque and colleagues ${ }^{23}$ performed a thorough analysis of Flemish $\mathrm{PhD}$ student mental health as compared to control groups from other highly educated demographics (those in the general population, those who are employed, and those who are higher education students obtaining a degree other than $\mathrm{PhD}$ ) using the 12-symptom scale General Health Questionnaire (GHQ-12). They found that PhD students were roughly 1.5-4 times at the risk of experiencing each of the 12 symptoms of anxiety/depression, compared to the three other groups. Further, 32\% of $\mathrm{PhD}$ students reported four or more symptoms, which classifies them as being at serious risk of developing depression and other common mental illnesses.

Barreira et al. reported that $18 \%$ of graduate students in economics, natural sciences and engineering scored at or above 10 on the PHQ-9 scale for exhibiting symptoms of moderate-to-severe depression and anxiety. This score corresponds to severity to such a degree that the symptoms would likely garner a formal diagnosis from a professional, according to the authors. They compare these rates to those for the age-matched general population, which were found in other studies to be $5.6 \%$ for depression and about $3.5 \%$ for anxiety ${ }^{86}$. Thus, graduate students were found to be 3-5 times more likely than the general population to experience moderate-to-severe depressive and anxious symptoms.

A brief review ${ }^{90}$ of seven studies on graduate student mental health showed a range of $43-44.7 \%$ for experiencing emotional/ stress-related problems, including symptoms of depression. The one exception to this rule was the Gloria \& Steinhardt study ${ }^{91}$ which found a depression rate of only $29 \%$ but that $58 \%$ classified as "languishing". One study featured in the review is a 2014 UC Berkeley study that employed the CES-D scale. It found that $47 \%$ of $\mathrm{PhD}$ students and $37 \%$ of Masters students scored within the clinical depression range ${ }^{75}$. These are similar to the results found by Evans et al., and not significantly higher than the percent of students at risk of mental illness found by Levecque et al. This study also corroborates Levecque et al.'s finding that higher education students outside of $\mathrm{PhD}$ programs, including Masters students, have slightly lower rates of mental illness relative to $\mathrm{PhDs}$.

Another particularly informative study was conducted by Garcia-Williams, Moffit, and Kaslow. It found that more than $50 \%$ of the graduate sample reported feelings of anxiety and $95.4 \%$ reported "feeling nervous or worrying a lot" within the past 4 weeks. Also, within the past 4 weeks, $34.4 \%$ scored moderateor-higher levels of depression on the PHQ-9, and $44.4 \%$ felt hopeless. Most strikingly, 7.3\% reported suicidal ideation, $2.3 \%$ reported forming suicide plans, and $1.7 \%$ had committed NSSI within the past 4 weeks ${ }^{66}$. For comparison, the ACHA NCHA found an NSSI rate of $3.2 \%$ in the past 12 months among graduate students ${ }^{45}$. Information from this section is gathered in Table 7.

\section{Do graduate students struggle more than undergraduate students?}

Despite the extra responsibilities and pressures faced by graduate students, there is evidence that their mental health is slightly-to-significantly better than that of undergraduates ${ }^{66,92}$. For example, the ACHA NCHA found that graduates had slightly lower rates of diagnosed depression (14.8\% vs $17.3 \%$ in undergraduates) and anxiety (19.5\% vs $22.8 \%$ in undergraduates $)^{45}$. Also, the ACHA NCHA graduate reference group showed lower rates of feelings of depression (32.9\% having felt "too depressed to function" in past 12 months, 28.4\% "experienced depression" in past 12 months ), anxiety (60.5\% having felt "overwhelming anxiety" in past 12 months, $16.6 \%$ in past 2 weeks), NSSI (3.3\%), suicide attempts ( $0.3 \%$ in past 12 months) compared to those in the undergraduate reference group $(42.8 \%$ and $32.9 \%$ for depression, $63 \%$ and $31 \%$ for anxiety, $8.5 \%$ for NSSI and $2 \%$ for suicide attempt, all in respective order $)^{45}$. 


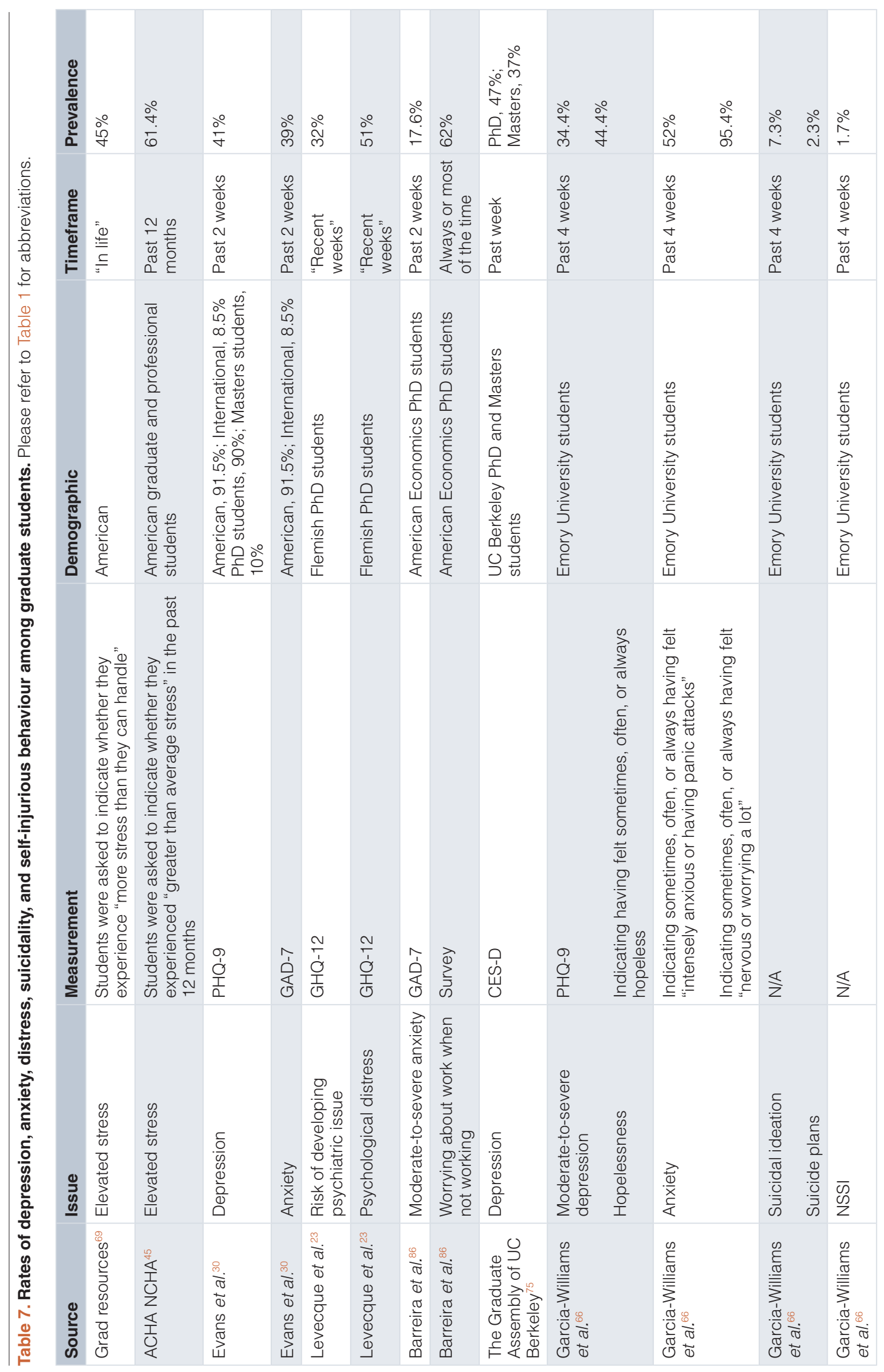




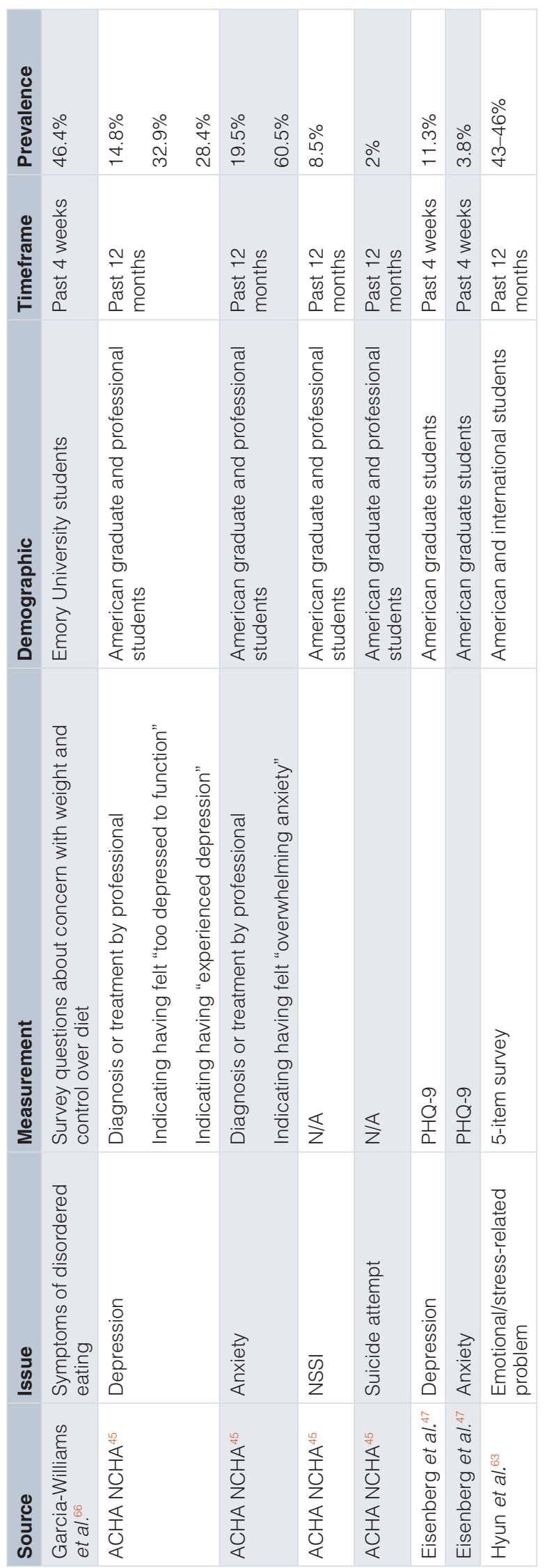


In contrast, the ACHA NCHA did find a slightly higher rate of suicidal ideation (past 12 months) among graduates $(12.7 \%$ versus $12 \%$ ), and other studies have also found that graduate students may have higher suicidality than undergraduates ${ }^{66}$. Meanwhile, Eisenberg and colleagues also found slightly lower rates of mental health issues among graduate students; with a prevalence rate of $11.3 \%$, they were 2.5 percentage points less likely to suffer from depression than undergraduates, and almost $10 \%$ less likely to suffer from anxiety (3.8\% versus $4.1 \%)^{56}$. In Gallagher and Taylor's report, $80 \%$ of the 125 student suicides reported in 2014 were carried out by undergraduates ${ }^{93}$. Most conclusively, Wyatt and Oswalt directly compared undergraduate and graduate mental health and found that undergraduates are significantly worse-off in that regard ${ }^{92}$.

These effects may be a result of the contradicting forces of increased pressure and of selection bias: graduate students face more adult responsibilities and higher academic pressure. However, in order to get into graduate school in the first place, students must be able to meet a high standard of academic functioning. It is likely that the slightly lower rates of mental illness among graduates reported by some studies are due to such selection bias. Students with severe mental health issues are less likely to be able to continue to graduate school.

\section{Medical and health studies students}

It has been suggested that medical students and other health science trainees have particularly high rates of mental distress ${ }^{25,46,84}$. For example, a Swedish study using the MDI (Major Depression Inventory) found that medical students have a depression rate of $12.9 \%$, more than $1.5 \mathrm{x}$ the prevalence they found in the general population $(7.8 \%)^{94}$. As a result, there is an abundance of mental health studies focussing on these disciplines specifically. A review of global literature, performed by Puthran et al., concluded that $28 \%$ of medical students worldwide could be classified as clinically depressed ${ }^{95}$. Notably, this study did not find a significant difference in depression prevalence between medical and non-medical students. Meanwhile, a review on Saudi Arabian health science student mental health by Alfaris and colleagues found a weighted average of $47 \%$, calculated from a range of results between $8-70 \%{ }^{46}$. However, this result may not be representative of those in North America. For example, the authors explain that the lowest end of the range (8\%) was from an American study, whereas the highest end (70\%) was from a Pakistani study. Finally, the global review of literature by Ibrahim and colleagues actually found a lower prevalence of depression in medical students: $25.6 \%$ (calculated from a range of $10.3-59 \%$ ), compared with $35.6 \%$ for non-medical students (calculated from a range of $10-84.5 \%$ ) $^{27}$. The authors note that this is contrary to expectation and suggest the explanation that medical students are perhaps better at recognizing their own mental health issues and reaching out for help. It is also possible that selection bias plays a role in this finding as well.

Turning to American studies, a study of Illinois pharmacy school students found that, on the PHQ-9 scale, 31.9\% registered as having mild depression, $16.9 \%$ as having moderate depression, $2.4 \%$ as having moderate-severe depression, and $1.2 \%$ as having severe depression. The study also noted that pharmacy students were twice as likely as the general population to report experiencing a depressive symptom ${ }^{79}$. Dyrbye et al. measured burnout among medical students and found a prevalence of 49.6-52.8\% using the Maslach Burnout Inventory ${ }^{96,97}$. More strikingly, the prevalence they found for suicidal ideation was $11.2 \%$ over the past 12 months, though they calculated that, if all non-respondents were assumed to experience no ideation, the lowest possible prevalence was $5.8 \%$. When respondents were asked instead if they had ever considered suicide at any point in their lives, the prevalence rose to just over a quarter. Wallin and Runeson, in another Swedish study, found even higher rates of suicidal ideation: $33 \%$ and $44 \%$ for students in their first and final years, respectively ${ }^{98}$.

Dyrbye and colleagues also compiled evidence for and against the claim that medical students experience elevated distress and rates of depression and anxiety compared to the general population. They conclude that the vast majority of studies with upper-year medical students found that they do indeed experience significantly poorer mental health than the general population ${ }^{28}$. This is summarized in Table 8 .

\section{Who is most at risk?}

Out of the studies included in this review, those that measured gender differences almost unanimously found that women are at higher risk for certain mental illnesses, such as major depression and anxiety, distress, self-harm, and/or suicidal ideation. One such study of the different trends between male and female undergraduate mental illness, Conley and colleagues speculate that males are more likely to avoid dealing with their emotions (avoidant coping), whereas females are more likely to try to acknowledge their feelings and try to deal with them. While avoidant coping is generally not considered healthy, it has not been conclusively linked to greater psychopathology in males and it could potentially be a better strategy for dealing with the stresses of university. The study suggests that female students' tendency to focus on their feelings in an attempt to remedy them may actually be exacerbating their distress ${ }^{99}$. Interestingly, this finding of increasing distress over time among females, but not males, was also found in a separate study on Canadian medical students. In this study, male students started the semester with elevated distress (one standard deviation above the general population average), whereas females started with average distress which increased to the elevated level (one standard deviation above the general population average) by the end of the semester ${ }^{100}$.

This higher propensity for distress may be somehow correlated with the finding that females have higher financial strain and insecurity. The Wisconsin-HOPE Lab found that females were 9 percentage points more food-insecure compared to males ${ }^{101}$. Stallman's study found that females were slightly more likely to report "frequent financial stress" and "constant financial stress", and less likely to report "no financial stress" as compared to males ${ }^{31}$. However, the author does not comment upon whether these differences are statistically significant. More conclusively, a UK study by the National Union of Students 
Table 8. Rates of depression, anxiety, distress, suicidality, and self-injurious behaviour among medical and health-studies students. Please refer to Table 1 for abbreviations.

\begin{tabular}{|c|c|c|c|c|c|}
\hline Source & Issue & Measurement & Demographic & Timeframe & Prevalence \\
\hline Dahlin et al. ${ }^{94}$ & Depression & MDI & $\begin{array}{l}\text { Karolinska Institute Medical } \\
\text { University students }\end{array}$ & Past 2 weeks & $12.9 \%$ \\
\hline Dahlin et al..$^{94}$ & Suicidality & $\begin{array}{l}\text { Thoughts } \\
\text { Thoughts } \\
\text { Attempt } \\
\text { (Meehan Inventory) }\end{array}$ & $\begin{array}{l}\text { Karolinska Institute Medical } \\
\text { University students }\end{array}$ & $\begin{array}{l}\text { Past } 12 \text { months } \\
\text { Ever } \\
\text { Ever }\end{array}$ & $\begin{array}{l}5.4 \% \\
28.8 \% \\
2.7 \%\end{array}$ \\
\hline Puthran et al. ${ }^{95}$ & Depression & $\begin{array}{l}\text { Varying (literature } \\
\text { review) }\end{array}$ & Global & N/A & $28 \%$ \\
\hline Alfaris et al. ${ }^{46}$ & Depression & BDI & Saudi Arabian & Past week & $\begin{array}{l}\text { Weighted mean } 47 \% \\
\text { (range, } 8-70 \% \text { ) }\end{array}$ \\
\hline Ibrahim et al. ${ }^{27}$ & Depression & $\begin{array}{l}\text { Varying (literature } \\
\text { review) }\end{array}$ & Global & Varying & $\begin{array}{l}\text { Weighted mean, } 25.6 \% \\
\text { (range, 10-84.5\%) }\end{array}$ \\
\hline Hunt \& Gable ${ }^{102}$ & $\begin{array}{l}\text { Moderate to severe } \\
\text { depression }\end{array}$ & PHQ-9 & Illinois pharmacy students & Past 2 weeks & $20.5 \%$ \\
\hline Wallin \& Runeson ${ }^{98}$ & Suicidal thoughts & Survey questions & $\begin{array}{l}\text { Karolinska Institute Medical } \\
\text { University students }\end{array}$ & Ever & $33-44 \%$ \\
\hline Wallin \& Runeson ${ }^{98}$ & Anxious symptoms & Survey questions & $\begin{array}{l}\text { Karolinska Institute Medical } \\
\text { University students }\end{array}$ & Ongoing & $12 \%$ \\
\hline Dyrbye et al. ${ }^{96}$ & Suicidality & $\begin{array}{l}\text { Consideration } \\
\text { Attempt } \\
\text { (Meehan Inventory) }\end{array}$ & $\begin{array}{l}\text { American University } \\
\text { students }\end{array}$ & $\begin{array}{l}\text { Past } 12 \text { months; } \\
\text { ever } \\
\text { Ever }\end{array}$ & $\begin{array}{l}5.8-11.2 \% ; 25.1 \% \\
1.9 \%\end{array}$ \\
\hline
\end{tabular}

reported that females are 1.5 times more likely to worry frequently about finances, compared to males ${ }^{103}$.

Additionally, the Global Young Academy found that women had a slightly more pessimistic view of their career prospects, giving lower estimates of their chances to become a professor or land an academic or teaching position. Overall, women gave their career prospects an average rating of 0.1 lower than males, on a scale of 1-5. Also, women were more likely to report lack of support from superiors (50.6\% versus $41.2 \%$ ) and job rationalization $(21.3 \%$ versus $13.1 \%)$, as well as gender discrimination $(17.1 \%$ versus $4.6 \%)$, as obstacles to their career ${ }^{104}$. However, the authors warn that an existing sampling bias due to overrepresentation of women in the survey was not corrected, so these values should not be viewed as conclusive.

While male students have lower psychological distress than female students, they comprise a much larger portion of student suicides $^{35}$. For example, in his 2014 survey of university counselling centres across America, Gallagher reported that $70 \%$ of that year's student suicide victims were male ${ }^{105}$. The UK Office for National Statistics reported that male highereducation students are almost three times as likely to commit suicide as females ${ }^{106}$. This is consistent with the general population: while females are more likely to have suicidal ideation and/or attempt suicide, males are much more likely to actually end their lives ${ }^{107}$. This could in part be due to differences in chosen method: males are twice as likely to use a firearm, whereas females are three times as likely to attempt to poison themselves ${ }^{107}$. Also, Bernaras and colleagues found that men were at a higher risk of doing "actual harm" to either themselves or others ${ }^{5}$.

Besides sex differences in the preferred method of suicide, another reason for the higher suicide rate among males is that they are less likely to access mental health services or partake in wellness practices, perceiving a higher stigma around discussing personal problems and seeking professional help ${ }^{27,108}$. Gallagher's 2010 National Survey of University Counselling Centres found that just $35 \%$ of student-counselling clients are male ${ }^{105}$. Bernaras and colleagues even cited this discomfort with disclosing personal issues as an explanation for the gender differences many studies have found in rates of psychological distress and related symptoms. Perhaps this gap is due in part to the fact that women are more likely to openly and honestly report their mental health issues and symptoms on surveys ${ }^{5}$. Also, Conley and colleagues reported that male students typically have less social support than females ${ }^{99}$, which may be another factor that discourages them from reaching out to seek help. Finally, studies on undergraduates report that females are significantly more prone to eating disorders ${ }^{54,99}$, whereas males are more prone to binge drinking ${ }^{54,109}$.

Studies including a racial component also found that racial minority students are at higher risk of distress and other mental health issues. Smith et al. found that minority students exhibited 
worse mental health than white students, even at universities that had a high concentration of students from ethnic minorities ${ }^{109}$. Eisenberg and colleagues found that white students were less likely to screen positive for major depression on the PHQ-9, compared to any other race, with students identifying as "other race" having the highest likelihood ${ }^{17,47}$. They also found that students identifying as multi-racial were more likely to experience major depression, suicidal ideation, and $\mathrm{NSSI}^{17}$. This evidence points to the possibility that students who do not easily fall into a single socially defined racial category experience additional stress. Richardson et al. corroborated claims that minority students experience poorer mental health, but interestingly, they found white students to be at higher risk of alcohol dependence than black and Asian students ${ }^{110}$. Notably, Dyrbye et al.'s review of North American medical students revealed no link between ethnicity and mental health ${ }^{28}$. It is possible that medical students have a higher socioeconomic status overall and therefore medical students from an ethnic minority do not experience more economic challenges than white medical students. Students of colour, especially black students, are less likely to seek mental health services compared to white students $^{62,111-113}$. Moreover, minority students may experience additional race-related stress, in the form of MEES (mundane extreme environmental stress, also called "microaggressions"), isolation, and stereotype threat ${ }^{12,111}$.

According to the HOPE Lab, minority students were at a higher risk of food and housing insecurity compared to white students, with the exception of Asian students, who were at the lowest risk out of all the racial categories ${ }^{101}$. Native American students were at the highest risk for food insecurity (55\%), housing insecurity (69\%), and homelessness (19\%), followed by black students $(54 \%, 55 \%$, and $13 \%$, respectively), and "mixed/other" students $(50 \%, 52 \%$, and $17 \%)$. Hispanic students were at a slightly lower risk $(47 \%, 51 \%$, and $10 \%)$, followed by Middle Eastern/Arab students $(43 \%, 49 \%$, and 12\%). White students had the second-lowest risks $(37 \%, 42 \%$, and $11 \%)$, followed by Asian students, who had the lowest risks across the board (36\%, 37\%, and 7\%). Native American and "mixed/other" students experienced the highest prevalence of homelessness ${ }^{101}$. The elevated risk of homelessness for "mixed/other" students may correlate with their higher risk of psychological distress. In the same vein, the CIRP reports that in America, students at historically black colleges and universities report higher levels of financial insecurity, with one in five students unsure of whether they had the financial means to complete their degree ${ }^{15}$.

It is likely that the link between ethnicity and socioeconomic status plays some role in the increased prevalence of mental health issues among minority students. Socioeconomic status has been linked to worse mental health ${ }^{35,114,115}$, reduced access to mental health services, and reduced wellness behaviour ${ }^{35,108}$. Eisenberg and colleagues found that even growing up in a lower- socioeconomic-status household predicted worse mental health in students ${ }^{47}$. In fact, a NUS Insight survey reports that $36 \%$ of students report that they worry about finances so much that it affects their mental health ${ }^{103}$. A British study found that self-reported financial stress and debt were strongly correlated to worse overall mental health, including depression, anxiety, stress and alcohol abuse. Interestingly, though, this study did not find that family affluence could predict mental health issues, in contrast to the findings by Eisenberg et al. ${ }^{110}$. Cuéllar and Roberts, therefore, argue that studies exploring the link between racial identity and mental health should also control for the mediating effect of socioeconomic status. In their analysis of survey responses gathered from Latino students, they found that socioeconomic status plays a much more significant role in poor mental health compared to ethnic identity ${ }^{114}$.

Interestingly, in a study of 1,773 undergraduates across four socioeconomic status groups, Rosenthal and Wilson found no disparities in mental health service utilization between sexes, socioeconomic status groups, or ethnicities ${ }^{62}$. The authors note that this is contradictory to the prevailing assumptions about service use disparity, but they stress that there are no identifiable errors or statistical anomalies that could have erroneously led to these results.

As may be expected, LGBTQ+ students face additional challenges, unique to their identity. There is evidence that homosexual students experience poorer mental health and higher suicidality compared to heterosexual students ${ }^{11,116}$ with bisexual students especially at risk. Kerr, Santurri \& Peters found female bisexual students to be 3.1 times as likely to report a depression diagnosis, twice as likely to report anxious and depressive symptoms, and almost five times as likely to report suicidality and self-harm, compared to heterosexual female students. Lesbian students were twice as likely to report a depression diagnosis, five times as likely to report self-harm, and about four times more likely to report suicidality, compared to heterosexual female students. Bisexual women were overall significantly more likely to report depressive and anxious symptoms and suicidality compared to lesbian and heterosexual women $^{116}$. Meanwhile, Liu and colleagues reported that bisexual students were 1.5 times more likely to report a mental health diagnosis or suicidality than homosexual students, and 3.9 times more likely compared to heterosexual students. Furthermore, they report that over half had experienced suicidal ideation and a quarter had made attempts on their lives ${ }^{111}$. Eisenberg and colleagues also found that bisexual students were at particular risk of experiencing depression ${ }^{47}$.

As before, this comes with a significantly increased risk of housing and food insecurity: homosexual students had greater risk than heterosexual students, and bisexual students had the highest risk of all. Bisexual students were about 10-15 percentage points more likely to report food and housing insecurity and homelessness compared to heterosexual students, and 5-7 percentage points more likely than homosexual students ${ }^{101}$.

Not just students from sexual-orientation minority experience additional distress and needs insecurity, but also students from a gender-identity minority as well. A study of transgender and non- binary students found that $85 \%$ reported a mental health issue, with $25 \%$ explicitly relating to the challenges of being a 
gender-identity minority to their poor mental health. Many trans/ non-binary students are reluctant to access mental health services due to the risk of landing a transphobic or ignorant counsellor. Slightly more than $25 \%$ of respondents described their previous counselling experiences as ambivalent or non-affirming towards trans/non-binary issues ${ }^{117}$. The obstacles facing gender minorities who need to access mental health services are particularly concerning in light of the fact that they are at much higher risk for mental illness ${ }^{30,111,117}$. Evans and colleagues found that transgender students were 12-21 percentage points more likely to report anxiety compared to cisgender males and females respectively, and 16-22 points more likely to report depression ${ }^{30}$. Liu and colleagues reported that transgender students were 1.9-2.4 times as likely to report mental health issues and suicidality compared to cisgender students. They have a much higher rate of distress compared even to bisexual students, with two-thirds experiencing suicidal ideation and one-third having made an attempt ${ }^{111}$. It is additionally concerning that some studies have reported an increase in the prevalence of transphobic bullying at universities ${ }^{118}$.

A report on LGBTQ+ scientists in the physical sciences may be indicative of some of the factors at play in LGBTQ+ students' mental health challenges: $18 \%$ of LGBTQ+ scientists, and in particular, $32 \%$ of non-binary scientists, reported being the target of discriminatory behaviour at their workplace ${ }^{119}$.

\section{What stops students from getting help?}

While great progress has recently been made in dismantling the stigma around mental health issues, stigma is likely still a primary obstacle standing between many students and the help they need ${ }^{119}$. Hussain et al. interviewed some of the first-year subjects in their study and concluded that stigma is still a concern among students who are considering seeking help. Students mentioned feeling that seeking help might be embarrassing, as they would appear unable to handle academic and social stresses. The authors further suggest that students in rural/small-town settings may feel that there is a higher social risk to seeking help, due to the reduced privacy/anonymity of such settings ${ }^{54}$.

Similarly, Eisenberg, Golberstein, and Gollust investigated the most common reasons that students who need help do not seek it. In total, $20 \%$ cited worrying about what others will think of them if they were in mental health treatment, $10 \%$ feared that it would somehow go onto their academic record and 9\% feared that their parents would find out. Besides stigma, 32\% reported simply lacking the time to seek help, and $8 \%$ lacked the finances. A total of $32 \%$ thought they would just get better by themselves over time, which may indicate a need for better awareness about the seriousness of mental health issues. It is also noteworthy that $51 \%$ said they felt that stress was just a regular part of school, though only $45 \%$ indicated that they felt they had no need for mental healthcare. A possible interpretation is that the $51 \%$ recognized they had more stress than they could handle, but thought it would be inappropriate to seek help for distressed caused by "normal/mundane" problems such as school $^{113}$.
Interestingly, Eisenberg and colleagues also found that students' own internalized stigma of mental illness is a bigger obstacle to seeking help than their perception of public stigma. In comparing students' own internalized stigma with their perception of public stigma, Eisenberg found large disparities, pointing to the possibilities that students either have an inflated sense of public stigma or are under-reporting their own internalized stigma $^{120}$. The review by Storrie, Ahern, and Tuckett compiles evidence that the vast majority of students with emotional problems and/or severe distress are not receiving treatment and attributes stigma as a key reason ${ }^{121}$.

In Gallagher's report, only $13 \%$ of people who had completed suicide had received counselling ${ }^{105}$, though this may be a case of selection bias: students in treatment would be less likely to resort to suicide. In another study on the persistence of student mental health problems, less than half of the students who had a persistent mental health problem over the two-year span of the study received help within that duration ${ }^{48}$. In Barreira et al.'s study of $\mathrm{PhD}$ students, only $27 \%$ of students with depression and $21 \%$ of students with anxiety were in treatment. Although this could simply reflect oversensitivity of the survey's screening instruments, only $27 \%$ of students who self-reported suicidal thoughts were in treatment, which indicates that a majority of students with mood disorders are not receiving treatment ${ }^{86}$. Similar numbers were reported by Garlow et al., who found that $84 \%$ of students with suicidal ideation and $85 \%$ of students who screened as moderately-severely-to-severely depressed on the PHQ-9 were also not receiving treatment ${ }^{50}$. According to Hunt and Eisenberg ${ }^{35}$, similar rates of treatment among mentally ill students (less than 25\%) were also reported by Blanco et al. ${ }^{122}$, though they also noted that this low rate of treatment is not significantly different from the rate among non-students. There is evidence suggesting that men experience greater stigma around mental illness and are therefore particularly unlikely to seek help ${ }^{123}$. This also seems to be case for Asian and Latino students ${ }^{120}$.

\section{Factors that could contribute to mental health concerns}

Sexual assault

Sexual victimisation has been positively linked to suicidal ideation, depressive feelings, psychological distress, and risktaking behaviour in university student samples of men and women $^{124,125}$. According to RAINN, American university students are in the age range with the highest risk for sexual assault, although female students are at a lower risk than female non-students ${ }^{126,127}$.

Estimates of university sexual assault frequency vary greatly. For university students of all genders and degree levels, RAINN cites a sexual assault frequency of $11.2 \%{ }^{126,127}$.

For female students, Stepakoff's review found between 13-27\% were survivors of sexual assault. Outlier studies estimate rates greater than $50 \%{ }^{124}$. American Association of Universities (AAU) statistics cited by RAINN are firmly within this range, reporting a sexual assault frequency of $23.1 \%$ among female undergraduates. The reported frequency for female graduate/ 
professional students is much lower, at $8.8 \% 128$. Furthermore, they report that only 1 in 5 female student victims report to law enforcement ${ }^{114}$, and only 1 in 6 receive assistance from victim services $^{127,128}$.

Conversely, male students are much more likely to be sexually assaulted than their non-student counterparts. The AAU's estimate is $5.4 \%$ of undergraduates and $2.2 \%$ for graduate/ professional students have been sexually assaulted ${ }^{127,128}$. Turchik reports a range of $18.5 \%-31 \%$ for rates of unwanted sexual contact in the past academic year ${ }^{125}$. Furthermore, Turchik reports that the range becomes $34-58 \%$ when male students are asked to report incidences since age $16^{125}$. Men are less likely to disclose and seek help for their unwanted sexual experience, due in large part to myths about male rape ${ }^{128}$.

Thus, it is important to educate male students in particular about their right to report, and to dispel stigma around being a male sexual assault victim. Finally, gender minorities are at an elevated risk of sexual assault and rape, especially genderqueer/gender non-conforming/trans-identifying males ${ }^{127,128}$.

A survey of graduate students across the fields of economics, engineering, and natural sciences found that $16 \%$ of graduate students have experienced sexual assault at some point during their $\mathrm{PhD}$ studies. Specifically, $21 \%$ of female students and $13 \%$ of male students reported such an experience. Overall, $62.5 \%$ of instances were perpetrated by peers whereas $19 \%$ were perpetrated by a professor ${ }^{86}$.

\section{Bullying}

It is well-known that bullying negatively impacts mental health ${ }^{118}$. Bullying in academia can happen by peers or by authorities (supervisors, professors, mentors, etc.). A common form of supervisor-student bullying is academic exploitation, in which a supervisor takes credit for a student's work ${ }^{129}$. In other cases, supervisor-student bullying can include making inappropriate, discriminatory, or derogatory comments ${ }^{130}$. In all of these cases, students can often feel as if they have no means of recourse, because they fear that their concerns will not be taken seriously by higher-ups, or that antagonizing their supervisor will impact their academic/professional careers ${ }^{129-131}$. Thus, it is difficult to comment on the frequency of these issues. The hierarchical nature of higher education makes it difficult for students to report their experiences, either because they are afraid of the consequences, or because they believe their experience is normal $^{130-132}$.

Yamada et al. investigated bullying in a study of Canadian graduate students ${ }^{133}$. They reported that overall, $21 \%$ of students reported experiencing bullying by their supervisor, though very low percentages of students reported that the bullying was frequent. They found that the most frequent bullying types were "destabilization" (changing goals/responsibilities without informing the student, persistently undermining or demoralizing the student, etc.), which was experienced in some form by $40 \%$ of respondents, and "isolation" (ignoring the student, neglecting to give them important information, restricting their non-academic activities), which was experienced in some form by $37 \%$ of respondents, and finally, "overwork" (unreasonable pressure or deadlines), which was experienced by $32.9 \%$ of respondents. The four most common sub-behaviours were "undue pressure to produce work" (31.7\%), "shifting goal posts without telling you" (28.8\%), "adding or removal of areas responsibility without consultation" (24.5\%), and "threat to personal standing" (26.6\%). In terms of authorship issues, $41.3 \%$ reported that a supervisor or other faculty member received honorary authorship on their work $^{133}$.

Finally, in Frank et al.'s study of 16 medical schools, up to $63 \%$ reported having experienced belittlement by a professor and $71 \%$ experienced belittlement by a resident. The rates of students reporting harassment by these groups were $21 \%$ and $27 \%{ }^{134}$. Issues between graduate students and supervisors are important to document, as Evans et al. found that a student's relationship with their supervisor has significant impact on their mental health ${ }^{30}$.

A well-studied form of bullying at the undergraduate level is cyberbullying. Kokkinos et al. mention that $1 / 3$ of students reported involvement in bullying through online methods, such as over social media. Their literature analysis reported a rate of $9 \%$ to over $50 \%$ for reports of student victimization ${ }^{135}$. Myers and Cowie report that students in fraternities/sororities, women, and LGBTQ+ students are particularly vulnerable ${ }^{118}$.

The recently identified practice of "mobbing" is another type of bullying that academic culture may particularly lend itself to. Mobbing occurs when a team of colleagues collude to exclude, isolate, and demean a specific target. According to Seguin, universities are particularly unable to deal with this subtle form of bullying because they presume to be objective institutions that are "above" social issues such as bullying. In reality, their antiharassment resources are unequipped to handle such situations. Issues often get passed off euphemistically as "personality clashes" and victims are left with no real recourse ${ }^{136}$.

\section{Financial strain and parenting}

The Wisconsin-HOPE Lab found striking amounts of needsinsecurity among American undergraduate students across 66 institutions. The authors report that $36 \%$ of students reported experiencing food and housing insecurity in the past month, and $9 \%$ were homeless in the past year. Needs insecurity was highest among community college students and marginalized groups ${ }^{101}$. The higher needs insecurity among marginalized groups is discussed in more detail in the "Who is most at risk?" section of this review.

Perhaps unsurprisingly, needs insecurity was also higher among student-parents. In four-year programs, they were 9 percentage points more likely to be food-insecure and 6 percentage points more likely to be housing-insecure. In two-year programs, these differences were even more exaggerated ${ }^{101}$. In their studies of medical students, Dyrbye and colleagues found that studentparents are more likely to drop out ${ }^{97}$ and more likely to screen for depression on the CES-D scale, though debate exists as to whether this elevated depression risk applies to fathers and mothers, or mothers only ${ }^{28}$. 
In the essay "Student-parents and higher education: a crossnational comparison", Brooks explores the unique challenges of being a student-parent and recommends cultural attitude shifts and institutional supports that are necessary to properly accommodate them. The author cites "the temporal demands of being both a student and a parent of a young child; the paucity of on-site childcare facilities; restrictive 'no child on campus' policies; late availability of educational timetables; inconvenient timing of lectures and acute financial pressures" as a few of these challenges, as well as the conflict between their identities and expectations as students versus parents ${ }^{137}$.

In a Nature article, Powell interviewed an American mother who describes the challenges of being a $\mathrm{PhD}$ student and early-career scientist in a country with no formalized paid parental leave. This article describes a similar lack of on-campus childcare services and provisions, such as private lactation rooms. It also highlights restrictive conference policies that do not allow speakers or attendees to bring their infants with them ${ }^{138}$. Ultimately, both pieces point to the problematic expectation that academics must forgo family for career success, leaving student-and-scientist-parents with little support. According to Powell, childbirth is likely to coincide with the most crucial stage of a female early scientist's career, forcing her to make difficult choices ${ }^{138}$. The GYA corroborates that scientist-mothers in particular point to work-life balance as an obstacle in their careers, significantly more than childless scientists or fathers ${ }^{104}$. Their recommendations are covered further in Table 9.

\section{Table 9. A summary of institutional and cultural changes recommended by the authors featured in this review.}

\begin{tabular}{|c|c|c|}
\hline Source & Issue & Recommendation \\
\hline Garlow et al..$^{50}$ & Student suicidality & $\begin{array}{l}\text { Outlines a method used at Emory University: An annual anonymous mental-health- } \\
\text { screening survey is sent to students over the internet; students with concerning } \\
\text { scores are urged to come for in-person help }\end{array}$ \\
\hline Evans et al. ${ }^{30}$ & $\begin{array}{l}\text { Mental health issues among } \\
\text { graduate students }\end{array}$ & $\begin{array}{l}\text { Establishing career development programs that can encourage mental wellness } \\
\text { while addressing common career-based concerns among graduate students } \\
\text { Educating staff about mental health issues via a "train-the-trainers" method of } \\
\text { relaying information among the staff network } \\
\text { Encouraging staff to endorse self-care and mindfulness as key to efficient work }\end{array}$ \\
\hline Woolston ${ }^{139}$ & $\begin{array}{l}\text { High stress levels experienced by } \\
\text { graduate students }\end{array}$ & $\begin{array}{l}\text { Establishing/joining a student-run or young- scientist-run community for advice } \\
\text { and support, such as the Cheeky Scientist Association } \\
\text { Seeking therapy } \\
\text { Getting involved with student association events, such as professional- } \\
\text { development or leisure activities } \\
\text { Encouraging graduate students to be firm and confident in their work-life } \\
\text { boundaries } \\
\text { Reaching out to other young scientists to show positivity and support } \\
\text { Encouraging out-of-lab public engagement activities } \\
\text { Broadening the model of acceptable research beyond just outcomes, so that it } \\
\text { also includes new research methods } \\
\text { Broadening the model of acceptable career paths beyond just tenure-track }\end{array}$ \\
\hline Powell 82 & $\begin{array}{l}\text { Lack of funding for young } \\
\text { scientists due to competition by } \\
\text { older, more experienced scientists }\end{array}$ & $\begin{array}{l}\text { Following the approach of funders such as The European Research Council } \\
\text { and NIGMS, which allocates a certain amount of grant money for early-career } \\
\text { researches only }\end{array}$ \\
\hline Woolston ${ }^{81}$ & $\begin{array}{l}\text { Overwork and burnout among } \\
\text { graduate students and young } \\
\text { scientists }\end{array}$ & $\begin{array}{l}\text { Shifting the focus from strictly the number of hours worked to the amount of } \\
\text { worked produced; encouraging students to be efficient and make the best of their } \\
\text { time rather than working longer and longer hours } \\
\text { Supervisors should be lenient about work hours and allow time for "life" }\end{array}$ \\
\hline Powell ${ }^{140}$ & $\begin{array}{l}\text { Burnout and overwork among } \\
\text { students }\end{array}$ & $\begin{array}{l}\text { Educating students to recognise the signs of burnout in themselves and others } \\
\text { Again, focusing on efficiency over hours worked } \\
\text { Recognising the importance of taking breaks, which should be short and frequent } \\
\text { rather than long and occasional. Breaks should be entirely removed from the } \\
\text { setting or topic of work. One interviewee suggests the "Pomodoro method": taking } \\
\text { a 3-5-minute break every } 25 \text { minutes of work, and occasionally taking an extended } \\
\text { 15-30-minutes break } \\
\text { Recognising that happiness is key for good productivity, and treating good spirits } \\
\text { as an important work strategy rather than merely an emotional consolation } \\
\text { Students would benefit from identifying their most productive time of day and } \\
\text { planning their biggest tasks accordingly } \\
\text { Using small, easy tasks to break up long, difficult tasks; small tasks can include } \\
\text { out-of- lab responsibilities such as household chores } \\
\text { Supervisors should be understanding about self- care and student needs }\end{array}$ \\
\hline
\end{tabular}




\begin{tabular}{|c|c|c|}
\hline Source & Issue & Recommendation \\
\hline Woolston ${ }^{141}$ & $\begin{array}{l}\text { Low self-esteem and isolation } \\
\text { among students, with a particular } \\
\text { focus on STEM and graduate } \\
\text { student issues }\end{array}$ & $\begin{array}{l}\text { Teaching students to recognise and fight Impostor Syndrome feelings; } \\
\text { encouraging them to celebrate their accomplishments rather than trivialising them } \\
\text { Normalising rejection; understanding that is a healthy part of any academic career } \\
\text { Reaching out to other students who are struggling } \\
\text { For gender/race minorities, joining an online community of researches in your field } \\
\text { who share aspects of your identity } \\
\text { Government-instituted community programs for collaboration between young } \\
\text { scientists, such as the Participatory Science Platform in New Zealand }\end{array}$ \\
\hline Wong ${ }^{83}$ & Students feel alone and/or unsure & Restructuring academia to emphasise and reward faculty mentorship of students \\
\hline Storrie et al. ${ }^{121}$ & $\begin{array}{l}\text { Accessibility and efficacy of } \\
\text { university counselling services }\end{array}$ & $\begin{array}{l}\text { Better communication between academics, university counselling, and community } \\
\text { counselling to create a more organised student- support network } \\
\text { Reducing stigma, emphasising confidentiality of mental health services, and } \\
\text { raising awareness of available help }\end{array}$ \\
\hline $\begin{array}{l}\text { Marcotte and } \\
\text { Levesque }^{25}\end{array}$ & $\begin{array}{l}\text { Distress and low self-esteem } \\
\text { among younger undergraduates }\end{array}$ & $\begin{array}{l}\text { This study explores the relationship between distress and sense of identity, and } \\
\text { suggests that this relationship is taken into account by counsellors; it could also } \\
\text { possibly be used in mental health screening } \\
\text { Helping students develop a solid sense of identity, which the authors show } \\
\text { correlates with better mental health } \\
\text { Setting up a program in which older students could mentor first-year students } \\
\text { to help navigate and normalise identity issues Implementing programs that can } \\
\text { contribute towards goal setting and value-formation }\end{array}$ \\
\hline Parkman $^{142}$ & $\begin{array}{l}\text { Imposter phenomenon feelings } \\
\text { and low self-esteem among } \\
\text { students at the undergraduate and } \\
\text { graduate levels }\end{array}$ & $\begin{array}{l}\text { Recognising the effect of imposter phenomenon on mental health and working to } \\
\text { address it in counselling, workshops, and orientations } \\
\text { Teaching students how to combat perfectionism and feelings of failure by focusing } \\
\text { on goal- setting and positive aspects of their identity }\end{array}$ \\
\hline Powell ${ }^{143}$ & & $\begin{array}{l}\text { Academia has an individualistic "winner takes all" culture, in which one person } \\
\text { typically receives all the glory for a scientific breakthrough, or all the blame for a } \\
\text { failure. } \\
\text { This article highlights the need to shift academia's perspective from individualistic } \\
\text { to collective, one in which academics help each other and work together } \\
\text { This could turn academia's stressful hypercompetitive environment into an open } \\
\text { and comfortable one } \\
\text { By extension, dismantling the elitism that allows/encourages higher-status } \\
\text { academics to be dismissive or rude to younger academics; as ecologist Emily } \\
\text { Bernhardt explains it in the article, "There's this idea that is' OK to be an awful } \\
\text { person as long as you are brilliant" }\end{array}$ \\
\hline $\begin{array}{l}\text { Goldrick-Rab } \\
\text { et al. }{ }^{101}\end{array}$ & Student need- insecurity & $\begin{array}{l}\text { Students can get involved in student-run organisations that fundraise to combat } \\
\text { need- insecurity and raise awareness } \\
\text { Universities should develop aid programs that are private and accessible, and } \\
\text { ensure that students know how to use them; or they should consider partnering } \\
\text { with existing aid charities }\end{array}$ \\
\hline $\begin{array}{l}\text { Goldberg } \\
\text { et al. }{ }^{117}\end{array}$ & $\begin{array}{l}\text { Trans and non-binary students' } \\
\text { reluctance to use mental health } \\
\text { services due to prejudiced or } \\
\text { ignorant practitioners }\end{array}$ & $\begin{array}{l}\text { Educating counsellors to recognise, but not overemphasise, trans/non-binary } \\
\text { issues in the context of counselling } \\
\text { Dispelling the narrow conceptualisation of transness among counsellors } \\
\text { (i.e. the idea that a patient must meet certain conditions to prove that they are } \\
\text { "trans enough") }\end{array}$ \\
\hline Barnett et al. ${ }^{12}$ & $\begin{array}{l}\text { Under-utilisation of mental health } \\
\text { services by black students; } \\
\text { unaddressed racial stress } \\
\text { experienced by black students }\end{array}$ & $\begin{array}{l}\text { Counselling should incorporate behavior-based theories and strategies that can } \\
\text { help black students deal with the duality of the expectations and identities they } \\
\text { take on as Black students in a Eurocentric education system } \\
\text { The authors also recommend cooking classes that teach students how to prepare } \\
\text { healthy foods on a budget, and transition classes to help deal with the change } \\
\text { from high school to university }\end{array}$ \\
\hline
\end{tabular}

\section{Wellness}

Wellness is a broad concept that endorses a holistic view of health, wherein physical mental, and emotional well-being are equally important. It embraces self-care, stress-relief and management, healthy emotional coping, mindfulness, and reaching out for help when necessary. As such, it emphatically promotes mental-health awareness and stigma reduction, and, more broadly, cultivation of good mental/emotional framework for coping with stress and grievances in a healthy manner ${ }^{144}$. A key tenet of wellness is the value of prevention over treatment ${ }^{145}$. Prevention is achieved by prioritizing an individual's well-being, being aware of one's health needs and adapting one's lifestyle accordingly. 
Focussing on staying healthy and being aware of signs of illness, whether physical or mental, is a more productive approach to health as opposed to waiting until after one is already sick. Physical wellness include exercising and eating well, emotional wellness can include building a social support group and implementing healthy coping strategies, and mental wellness can include mindfulness activities and counselling, if necessary. Wellness may have been considered unimportant, or even a distraction from work, in the past, but cultural attitudes are shifting, as evidence amasses showing that employee happiness is key to maximizing productivity ${ }^{146,147}$.

Several studies have assessed the effectiveness of wellness practices such as meditation, mindfulness, counselling and mindful physical exercise. Conley, Durlak, and Dickson performed an analysis of 83 studies to assess the effectiveness of mental health promotion and prevention programs in higher education. Their review confirms the effectiveness of wellness programs in alleviating depressive and anxious symptoms and highlights cognitive behavioural therapy and mindfulness as the two most effective wellness strategies. The study further concluded that supervised, skill-oriented, class-format wellness programs are the most effective ${ }^{148}$. In their own experiment with a wellness seminar for first- year students, Conley and colleagues once again found that attendance and engagement with the wellness program are key to seeing improvements. Participants who regularly attended wellness seminars and practiced the skills they were taught showed better psychosocial and academic adjustment and better stress management ${ }^{149}$.

In another such review, Fernandez and colleagues examined the effectiveness of university mental health promotion and intervention programs, as well as the qualitative validity of the studies being analysed. The topic of the studies analysed varied greatly, so it is difficult to generalize their results here. However, their assessment of the program efficacy, combined with validity considerations, had an overall mixed tone. For example, a 1984 University of Illinois policy mandating students with suicidal ideation to receive four therapy sessions appeared to reduce suicides by $72 \%$, but oddly, graduate/professional student suicides rose by $94.6 \%$ following this policy ${ }^{150}$. A Chinese study on the impacts of a "youth development" wellness course reported that it was effective in increasing positive and hopeful feelings, but Fernandez and colleagues deemed the study to be of questionable credibility due to its lack of detail ${ }^{151}$. A third study found that subjecting medical students to a stressmanagement lecture reduced their stress by $46.7 \%$, but again, it was deemed of low-credibility due to its lack of control group. Also, many other studies included did not find that such programs had any significant positive impacts. One repeated finding among studies in the review that did seem conclusive, however, was the impact of grading systems on student health: grading systems with fewer increments seemed to reduce stress, depression, and anxiety $^{151}$.

Universities are trying a variety of approaches to improve student mental health. For example, a few studies have explored the possibility of using tai-chi to foster wellness among students. One such study found no significant effects on mental health ${ }^{152}$, but another study found that tai chi chuan significantly decreased anxiety and improved sleep quality among young adults $^{153}$. In fact, a systematic review of the impact of tai chi on higher-education student mental health concluded that it is an effective method of reducing anxious and depressive symptoms among students ${ }^{154}$. As mentioned earlier, mindfulness has been a hot topic in student wellness discussions. Vidic \& Cherup reported that mindfulness relaxation was so effective among a sample of college students, that the test group went from higher stress than the control group to lower stress ${ }^{155}$.

In a review of empirical mindfulness studies, Keng, Smoski, \& Robins analyse a growing body of credible evidence that general mindfulness practices have a positive impact of mental health ${ }^{156}$.

However, the two university-sample studies in the review have conflicting findings: Bluth et al. found that mindfulness can uplift bad mood in students ${ }^{157}$, whereas Kuehner, Huffziger \& Liebsch did not find any significant impact ${ }^{158,159}$. The authors explain that this may be due to differences in sample or in methodology $y^{156}$. Cook recommends the usage of cognitive behavioural therapy and wellness courses to alleviate student mental distress, based on evidence supporting their effectiveness ${ }^{119}$. Cook references Brown \& Schiraldi, who found cognitive behavioural therapy to be significantly more effective in stress-reduction than a conventional stress-management course among students. Similarly, Kitzrow compiles evidence on the positive impact of counselling on both student mental health and academic performance ${ }^{32}$.

Combining the wellness principles of mindfulness and exercise, Caldwell et al. studied the benefits of mindfulness established through movement-based courses for university students. They reported that that such courses were successful in reducing negative arousal and the prevalence of insomnia, but mood changes were only statistically significant through the mediating factor of mindfulness: students who showed an increase in mindfulness (via the Five Facet Mindfulness Questionnaire) also showed an increase in positive feelings, relaxation, self-regulatory efficacy, and sleep quality, and a decrease in perceived stress ${ }^{154}$. Finally, this paper also includes recommendations from papers and articles on policy and attitude changes that can hopefully make academia a more welcoming and less stressful environment. For convenience, these are presented in Table 9 .

\section{Conclusions}

As shown in this review, there is a plethora of studies covering various aspects of student mental health, using diverse measurement tools and consequently, finding a very broad range of prevalence. Even among two studies using the same measurement tool, the reported prevalence of mental illness may differ significantly, depending on what level of symptom severity the authors choose as the cut-off.

Continuing to refine and standardize measurement tools seems necessary. Given the numerous strains and concerns specific to students and trainees in academia, it would seem appropriate 
that studies should view student wellness within the context of these challenges and continue assessing student mental health in comparison to that of the general population. Such comparisons illustrate whether student-specific challenges contribute to poor mental health, and therefore direct the approach of student wellness initiatives. For example, student wellness initiatives can guide students to deal with student-specific challenges or recommend changes to mitigate these challenges at the institutional level, rather than simply directing students to mental health counselling. Of course, as indicated by even the lower end of the prevalence ranges in this review, ensuring that university mental health counselling is well-staffed, well-resourced and welleducated is paramount to student well-being. This review merely recommends that student mental health be viewed within the context of student-specific challenges and that institutions and institutionalized counselling focus on helping students to deal with these issues.

\section{Data availability}

No data is associated with this article.
1. Morgan JF, Reid F, Lacey JH: The SCOFF questionnaire: a new screening tool for eating disorders. West J Med. 2000; 172(3): 164-5. PubMed Abstract | Publisher Full Text | Free Full Text

2. American Psychological Association: Beck Depression Inventory. Am Psychol Assoc.

Reference Source

3. Benton SA, Robertson JM, Tseng WC, et al:: Changes in counseling center client problems across 13 years. Prof Psychol. 2003; 34: 66-72. Publisher Full Text

4. American Psychological Association: Center for Epidemiological StudiesDepression. Am Psychol Assoc.

Reference Source

5. Bernaras E, Cerretani P, Garay B: Prevalence and severity of psychologica problems in university students. Brit J Guid Couns. 2018; 46(4): 418-428. Publisher Full Text

6. Psychology Foundation of Australia: Depression anxiety stress scales (DASS) Psychol Found Aust. 2018. Reference Source

7. Psychiatry \& Behavioral Health Learning Network: Generalized Anxiety Disorder $\mathbf{- 7}$ (GAD-7). Psychiatry Behav Heal Learn Netw. Reference Source

8. GAIN Coordinating Center: GAIN Instruments. Chestnut Heal Syst. Reference Source

9. Assessment GL: General Health Questionnaire. GL Assess. Reference Source

10. Solutions S: Kessler Psychological Distress Scale (K10). Stat Solut. 2014. Reference Source

11. PsychTools: Major Depression Inventory (MDI). PsychTools. 2018 Reference Source

12. Barnett TM, McFarland A, Miller J, et al.: Physical and Mental Health Experiences Among African American College Students. Soc Work Public Heal. 2019; 34(2): 145-57.

PubMed Abstract | Publisher Full Text

13. Framingham J: Minnesota Multiphasic Personality Inventory (MMPI) PsychCentral. 2018. Reference Source

14. American Psychological Association: Patient Health Questionnaire (PHQ-9 \& PHQ-2). Am Psychol Assoc. Reference Source

15. Pryor JH, DeAngelo L, Blake LP: The American freshman: national norms Fall 2011. Coop Institutional Res Progr High Educ Res Inst UCLA. 2011. Reference Source

16. Fullick M: My grief lies all within"-PhD students, depression \& attrition. Univ Aff. 2011. Reference Source

17. Eisenberg D, Hunt J, Speer N: Mental health in American colleges and universities: variation across student subgroups and across campuses. J NerV Ment Dis. 2013; 201(1): 60-7.

PubMed Abstract | Publisher Full Text

18. Rudgard O: Universities have a suicide problem as students taking own lives overtakes general population. The Telegraph. 2018. Reference Source

19. Bishop J: The changing student culture: implications for counsellors and administrators. J Coll Stud Psychother. 1993; 6(3-4): 37-57. Publisher Full Text

20. Boujut $\mathrm{E}$, Koleck M, Bruchon-Schweitzer M, et al:: La santé mentale chez les étudiants : suivi d'une cohorte en première année d'université. Ann Med Psychol (Paris). 2009; 167(9): 662-8.

Publisher Full Text
21. Coughlan S: Rising number of stressed students seek help. BBC. 2015. Reference Source

22. Maher B, Sureda Anfres M: Young scientists under pressure: what the data show. Nature. 2016; 538(7626): 444.

PubMed Abstract | Publisher Full Text

23. Levecque K, Anseel F, De Beuckelaer A, et al:: Work organization and mental health problems in PhD students. Res Policy. 2017; 46(4): 868-79. Publisher Full Text

24. Wallis T, Kelley D: Trends in academia: the reality of tenure track. Insid Sch. 2018. Reference Source

25. Marcotte J, Lévesque G: Anxiety and well-being among students in a psychoeducation program: The mediating role of identity. J Coll Stud Dev. 2018 59(1): 90-104. Publisher Full Text

26. Editorial: Misspent youth. Nature. 2016; 538: 427

27. Ibrahim AK, Kelly SJ, Adams CE, et al:: A systematic review of studies of depression prevalence in university students. J Psychiat Res. 2013; 47(3): 391-400.

PubMed Abstract | Publisher Full Text

28. Dyrbye LN, Thomas MR, Shanafelt TD: Systematic review of depression, anxiety, and other indicators of psychological distress among U.S. and Canadian medical students. Acad Med. 2006; 81(4): 354-73. PubMed Abstract | Publisher Full Text

29. Adlaf EM, Gliksman L, Demers A, et al:: The prevalence of elevated psychological distress among Canadian undergraduates: findings from the 1998 Canadian Campus Survey. J Am Coll Health. 2001; 50(2): 67-72. PubMed Abstract | Publisher Full Text

30. Evans TM, Bira L, Gastelum JB, et al:: Evidence for a mental health crisis in graduate education. Nat Biotechnol. 2018; 36(3): 282-4. PubMed Abstract | Publisher Full Text

31. Stallman HM: Psychological distress in university students: a comparison with general population data. Aust Psychol. 2010; 45(4): 249-57. Publisher Full Text

32. Kitzrow MA: The mental health needs of today's college students: challenges and recommendations. NASPA J. 2009; 46(4): 646-60. Publisher Full Text

33. Twenge JM, Gentile B, DeWall CN, et al.: Birth cohort increases in psychopathology among young Americans, 1938-2007: A cross-temporal meta-analysis of the MMPI. Clin Psych Rev. 2010; 30(2): 145-54. PubMed Abstract | Publisher Full Text

34. Sharkin BS: Assessing changes in categories but not severity of counseling center clients' problems across 13 years: Comment on Benton, Robertson, Tseng, Newton, and Benton (2003). Prof Psychol Res Pr. 2004; 35(3): 313-5. Publisher Full Text

35. Hunt J, Eisenberg D: Mental health problems and help-seeking behavior among college students. J Adolesc Health. 2010; 46(1): 3-10. PubMed Abstract | Publisher Full Text

36. Gallagher RP: National survey of counselling center directors. J Coll Stud Psychother. 2010; 6: 37-57. Reference Source

37. Sharkin BS: Increasing severity of presenting problems in college counseling centers: a closer look. J Couns Dev. 1997; 75(4): 275-81. Publisher Full Text

38. Jane Costello E, Erkanli A, Angold A: Is there an epidemic of child or adolescent depression? J Child Psychol Psychiatry. 2006; 47(12): 1263-71. PubMed Abstract | Publisher Full Text

39. Strepparava MG, Bani M, Zorzi F, et al:: Does the severity of psychopathology of Italian students receiving counselling services increase over time? A 5-year analysis and a comparison with a clinical and non-clinical sample. Clin Psychol 
Psychother. 2017; 24(6): 01448-01454. PubMed Abstract | Publisher Full Text

40. Cornish J, Riva M, Henderson M, et al.: Perceived distress in university counseling center clients across a six-year period. J Coll Stud Dev. 2000; 41(1): 104-9. Reference Source

41. Berger $\mathrm{H}$, Granke G, Hofmann F, et al.: Mental health of students and its development between 1994 and 2012. Ment Heal Prev. 2015; 3: 48-56. Publisher Full Text

42. Franke GH, Jagla M, Petrowski K, et al.: Psychological distress in students today and 20 years ago. Ment Heal Prev. 2017; 5: 1-4. Publisher Full Text

43. Furr SR, McConnell GN, Westefeld JS, et al.: Suicide and depression among college students: A decade later. Prof Psychol Res Pr. 2001; 32(1): 97-100. Publisher Full Text

44. Pledge DS, Lapan RT, Heppner PP, et al:: Stability and severity of presenting problems at a university counseling center: a 6-year analysis. Prof Psychol Res Pr. 1998; 29(4): 386-389. Publisher Full Text

45. American College Health Association: American College Health AssociationNational College Health Assessment II: Canadian Reference Group Executive Summary Fall 2018. Am Coll Heal Assoc. 2018.

Reference Source

46. Alfaris E, Irfan F, Qureshi R, et al:: Health professions' students have an alarming prevalence of depressive symptoms: exploration of the associated factors. BMC Med Educ. 2016; 16(1): 279. PubMed Abstract | Publisher Full Text | Free Full Text

47. Eisenberg D, Gollust SE, Golberstein E, et al:: Prevalence and correlates of depression, anxiety, and suicidality among university students. $A m$ Orthopsychiatry. 2007; 77(4): 534-42. PubMed Abstract | Publisher Full Tex

48. Zivin K, Eisenberg D, Gollust SE, et al:: Persistence of mental health problems and needs in a college student population. J Affect Disord. 2009; 117(3): 180-5 PubMed Abstract | Publisher Full Text

49. Farrer LM, Gulliver A, Bennett K, et al.: Demographic and psychosocial predictors of major depression and generalised anxiety disorder in Australian university students. BMC Psychiatry. 2016; 16: 241 PubMed Abstract | Publisher Full Text | Free Full Text

50. Garlow SJ, Rosenberg J, Moore JD, et al: Depression, desperation, and suicida ideation in college students: results from the American Foundation for Suicide Prevention College Screening project at Emory University. Depress Anxiety. 2008; 25(6): 482-8

PubMed Abstract | Publisher Full Text

51. Gress-Smith JL, Roubinov DS, Andreotti C, et al.: Prevalence, severity and risk factors for depressive symptoms and insomnia in college undergraduates. Stress Heal. 2015; 31(1): 63-70.

PubMed Abstract | Publisher Full Text

52. Bayram N, Bilgel N: The prevalence and socio-demographic correlations of depression, anxiety and stress among a group of university students. Soc Psychiatry Psychiatr Epidemiol. 2008; 43(8): 667-72. PubMed Abstract | Publisher Full Text

53. Galindo SB, Moreno IM, Munoz JG: Prevalencia de ansiedad y depresión en una población de estudiantes universitarios: factores académicos y sociofamiliares asociados. Clin y Salud. 2009; 20(2): 177-187. Reference Source

54. Hussain R, Guppy M, Robertson S, et al.: Physical and mental health perspectives of first year undergraduate rural university students. $B M C$ Public Health. 2013; 13: 848

PubMed Abstract | Publisher Full Text | Free Full Text

55. Neale I, Piggott L, Hansom J, et al:: Student resilience: unite students insight report. Unite Students. 2016. Reference Source

56. Ziven K, Eisenberg D, Gollust SE, et al.: Prevalence of mental health problems and needs in a college population. J Affect Disord. 2009; 117(3): 180-5. PubMed Abstract | Publisher Full Text

57. Pereira S, Reay K, Bottell J, et al.: University Student Mental Health Survey 2018. Insight Netw Dig-in. 2018. Reference Source

58. Kerr H: Mental distress survey overview. NUS RUS. 2013. Reference Source

59. Brown P: The invisible problem? Improving students' mental health. High Educ Policy Inst Report 88. 2016.

Reference Source

60. Bruffaerts R, Mortier P, Kiekens G, et al:: Mental health problems in college freshmen: Prevalence and academic functioning. J Affect Disord. 2018; 225: 97-103.

PubMed Abstract | Publisher Full Text | Free Full Text

61. Bírá É, Ádány R, Kása K: Mental health and behaviour of students of public health and their correlation with social support: a cross-sectional study. $B M C$ Public Health. 2011; 11: 871.

PubMed Abstract | Publisher Full Text | Free Full Text

62. Rosenthal B, Wilson WC: Mental health services: use and disparity among diverse college students. J Am Coll Health. 2008; 57(1): 61-8. PubMed Abstract | Publisher Full Text

63. Hyun J, Quinn B, Madon T, et al.: Mental health need, awareness, and use of counselling services among international graduate students. J Am Coll Health. 2007; 56(2): 109-18

PubMed Abstract | Publisher Full Text

64. Hyun JK, Quinn BC, Madon T, et al:: Graduate student mental health: Needs assessment and utilization of counseling services. J Coll Stud Dev. 2006; 47(3): 247-266.

Publisher Full Text

65. Eisenberg D, Hunt J, Speer N: Mental Health in American Colleges and Universities: variation across student subgroups and across campuses. J Nerv Ment Dis. 2013; 201(1): 60-7.

PubMed Abstract | Publisher Full Text

66. Garcia-Williams AG, Moffitt L, Kaslow NJ: Mental health and suicidal behavior among graduate students. Acad Psychiatr. 2014; 38(5): 554-60.

PubMed Abstract | Publisher Full Text

67. Woolston C: Graduate survey: Uncertain futures. Nature. 2015; 526(7574): 597-600.

PubMed Abstract | Publisher Full Text

68. Woolston C: Graduate survey: A love-hurt relationship. Nature. 2017; 550 549-552.

Publisher Full Text

69. Concerns THE: Stress and Relief for American Graduate Students: Results from a Nationwide Survey. Grad Resources. 2011.

Reference Source

70. Charbonneau L: Producing more PhDs. Univ. Affiars. 2010. Reference Source

71. Larson RC, Ghaffarzadegan N, Xue Y: Too Many PhD Graduates or Too Few Academic Job Openings: The Basic Reproductive Number $R_{0}$ in Academia. Syst Res Behav Sci. 2014; 31(6): 745-750.

PubMed Abstract | Publisher Full Text | Free Full Text

72. McKenna L: The Ever Tightening Job Market for PhDs. The Atlantic. 2016. Reference Source

73. National Science Foundation: Doctorate recipients from U.S. Universities. NatI Sci Found. 2015

Reference Sourc

74. Sutton A: Academic aspirations. Phys. World. 2015; 18 Reference Source

75. Panger G, Tryon J, Smith A: The Graduate Assembly Graduate Student Happiness \& Well-Being Report 2014. Grad Assem. UC Berkeley. 2014. Reference Source

76. Herzig RM: Suffering For Science: Reason and Sacrifice in Modern America New Brunswick: Rutgers University Press; 2005.

Publisher Full Text

77. Diamandis EP: A Key to Success Is the Key that Opens and Closes the Lab Door. J Appl Lab Med. 2019; 4(1): 135-136.

PubMed Abstract | Publisher Full Text

78. Woolston C: Mental health in academia is topic of the week at a sold-out UK meeting. Nature. 2019

Publisher Full Text

79. Woo E: "A toxic culture of overwork": inside the graduate student health crisis. Stanford Dly. 2019.

Reference Source

80. Kim $Y$, Faber $E$ : What medicine can teach academia about preventing burnout Nat Careers. 2019. Reference Source

81. Woolston C: Workplace habits: Full-time is full enough. Nature. 2017; 546 $175-177$.

Publisher Full Text

82. Powell K: Young, talented and fed-up: scientists tell their stories. Nature. 2016; 538(7626): 446-449.

PubMed Abstract | Publisher Full Text

83. Wong P: How to humanize higher education and reduce human suffering. Int Netw Pers Mean. page President's Column. 2006 Reference Source

84. Duffy M, Thanhouser C, Derry H: A lack of evidence for six times more anxiety and depression in US graduate students than in the general population. Nat Biotechnol. 2019; 37(7): 711-712. PubMed Abstract | Publisher Full Text

85. Diamandis EP: Getting noticed is half the battle. Science. 2015; 349(6244): 206 PubMed Abstract | Publisher Full Text

86. Barreira $\mathrm{P}$, Basilico M, Bolotnyy V: Graduate student mental health: lessons from American economics departments. Harvard Univ. 2018. Reference Source

87. Catcheside K: Removing the barriers to postgraduate education. Guard. 2011. Reference Source

88. Aguisanda F: At the end of the road, a new start. Science. 2018; 362(6418): 1078 PubMed Abstract | Publisher Full Text

89. Smith E, Brooks Z: Graduate student mental health 2015. Natl Assoc Grad 
Students. 2015.

Reference Source

90. Tsai JW, Muindi F: Towards sustaining a culture of mental health and wellness for trainees in the biosciences. Nat Biotechnol. 2016; 34(3): 353-5. PubMed Abstract | Publisher Full Text

91. Gloria CT, Steinhardt MA: Flourishing, languishing, and depressed postdoctoral fellows: Differences in stress, anxiety, and depressive symptoms. J Postdoc Aff. 2013; 3(1): 1-9. Reference Source

92. Wyatt TW, Oswalt SB: Comparing mental health issues among undergraduate and graduate students. Am J Heal Educ. 2013; 44(2): 96-107. Publisher Full Text

93. Gallagher RP, Taylor R: National Survey of College Counselling. Am Coll Couns Assoc. 2014.

Reference Source

94. Dahlin M, Joneborg N, Runeson B: Stress and depression among medical students: a cross-sectional study. Med Educ. 2005; 39(6): 594-604. PubMed Abstract | Publisher Full Text

95. Puthran R, Zhang MW, Tam WW, et al:: Prevalence of depression amongst medical students: a meta-analysis. Med Educ. 2016; 50(4): 456-68. PubMed Abstract | Publisher Full Text

96. Dyrbye LN, Thomas MR, Massie FS, et al.: Burnout and suicidal ideation among U.S. medical students. Ann Intern Med. 2008; 149(5): 334-41. PubMed Abstract | Publisher Full Text

97. Dyrbye LN, Massie FS Jr, Eacker A, et al:: Relationship between burnout and professional conduct and attitudes among US medical students. JAMA. 2010; 304(11): 1173-80.

PubMed Abstract | Publisher Full Text

98. Wallin U, Runeson B: Attitudes towards suicide and suicidal patients among medical students. Eur Psychiatry. 2003; 18(7): 329-33.

PubMed Abstract | Publisher Full Text

99. Conley CS, Kirsch AC, Dickson DA, et al.: Negotiating the tansition to college: developmental trajectories and gender differences in psychological functioning, cognitive-affective strategies, and social well-being. Emerg Adulthood. 2014; 2(3): 195-210. Publisher Full Text

100. Vitaliano PP, Maiuro RD, Russo J, et al:: Medical student distress. A longitudina study. J Nerv Ment Dis. 1989; 177(2): 70-6. PubMed Abstract | Publisher Full Text

101. Goldrick-Rab S, Richardson J, Schneider J, et al:: Still hungry and homeless in college. Wisconsin HOPE Lab. 2018. Reference Source

102. Hunt K, Gable KN: Prevalence of depressive symptoms and obsessivecompulsive personality traits among pharmacy students. Curr Pharm Teach Learn. 2013; 5(6): 541-5. Publisher Full Text

103. Finance F: NUS insight: financial woes affecting mental health. Futur Financ. 2016. Reference Source

104. Friesenhahn I, Beaudry C: The global state of young scientists-project report and recommendations. Glob Young Acad. 2015 Reference Source

105. Gallagher R: National Survey of College Counseling Centers. Int Assoc Couns Serv. 2014.

Reference Source

106. Caul S: Estimating suicide among higher education students, England and Wales: experimental statistics. Off Natl Stat. 2018 Reference Source

107. National Institute of Mental Health: Suicide. NIH. 2017. Reference Source

108. Lyssenko L, Müller G, Kleindienst N, et al:: Life Balance - a mindfulness-based mental health promotion program: conceptualization, implementation, compliance and user satisfaction in a field setting. BMC Public Health. 2015; 15: 740. PubMed Abstract | Publisher Full Text | Free Full Text

109. Smith KM, Chesin MS, Jeglic EL: Minority college student mental health: Does majority status matter? implications for college counseling services. J Multicult Couns Devel. 2014; 42(2): 77-92. Publisher Full Text

110. Richardson T, Elliott P, Roberts R, et al.: A Longitudinal Study of Financial Difficulties and Mental Health in a National Sample of British Undergraduate Students. Community Ment Health J. 2017; 53(3): 344-52. PubMed Abstract | Publisher Full Text | Free Full Text

111. Liu CH, Stevens C, Wong SHM, et al:: The prevalence and predictors of mental health diagnoses and suicide among U.S. college students: Implications for addressing disparities in service use. Depress Anxiety. 2019; 36(1): 8-17. PubMed Abstract | Publisher Full Text | Free Full Text

112. Garland AF, Lau AS, Yeh M, et al.: Racial and ethnic differences in utilization of mental health services among high-risk youths. Am J Psychiatry. 2005; 162(7) 1336-43.

PubMed Abstract | Publisher Full Text

113. Eisenberg D, Golberstein E, Gollust SE: Help-seeking and access to mental health care in a university student population. Med Care. 2007; 45(7): 594-601. PubMed Abstract | Publisher Full Text
114. Cuéllar I, Roberts RE: Relations of depression, acculturation, and socioeconomic status in a Latino sample. Hisp J Behav Sci. 1997; 19(2): 230-8. Publisher Full Text

115. Kessler RC, Chiu WT, Demler O, et al:: Prevalence, severity, and comorbidity of 12-month DSM-IV disorders in the National Comorbidity Survey Replication. Arch Gen Psychiatry. 2005; 62(6): 617-27.

PubMed Abstract | Publisher Full Text | Free Full Text

116. Kerr DL, Santurri L, Peters P: A comparison of lesbian, bisexual, and heterosexual college undergraduate women on selected mental health issues. J Am Coll Health. 2013; 61(4): 185-94.

PubMed Abstract | Publisher Full Text

117. Goldberg A, Kuvalanka K, Budge S, et al: Health care experiences of transgender binary and nonbinary university students. Couns Psychol. 2019; 47(1): 59-97. Publisher Full Text

118. Myers CA, Cowie H: Bullying at university: the social and legal contexts of cyberbullying among university students. J Cross Cult Psychol. 2017; 48(8): $1172-82$ Publisher Full Text

119. Cook LJ: Striving to help college students with mental health issues. J Psychosoc Nurs Ment Health Serv. 2007; 45(4): 40-4. PubMed Abstract | Publisher Full Text

120. Eisenberg D, Downs MF, Golberstein E, et al.: Stigma and help seeking for mental health among college students. Med Care Res Rev. 2009; 66(5): 522-41. PubMed Abstract | Publisher Full Text

121. Storrie K, Ahern K, Tuckett A: A systematic review: Students with mental health problems--a growing problem. Int J Nurs Pract. 2010; 16(1): 1-6. PubMed Abstract | Publisher Full Text

122. Blanco C, Okuda M, Wright C, et al:: Mental health of college students and their non-college-attending peers: results from the National Epidemiologic Study on Alcohol and Related Conditions. Arch Gen Psychiatry. 2008; 65(12): 1429-37. PubMed Abstract | Publisher Full Text | Free Full Text

123. Clement $S$, Schauman $O$, Graham T, et al.: What is the impact of mental healthrelated stigma on help-seeking? A systematic review of quantitative and qualitative studies. Psychol Med. 2015; 45(1): 11-27. PubMed Abstract | Publisher Full Text

124. Stepakoff S: Effects of sexual victimization on suicidal ideation and behavior in U.S. college women. Suicide Life Threat Behav. 1998; 28(1): 107-26. PubMed Abstract

125. Turchik JA: Sexual victimization among male college students: assault severity, sexual functioning, and health risk behaviors. Psychol Men Masc. 2012; 13(3): 243-55. Publisher Full Text

126. Sinozich $S$, Langton $L$ : Rape and sexual victimization among college-aged females, 1995-2013. Bur Justice Statsitics US Dep Justice. 2014. Reference Source

127. RAINN: Campus sexual violence: statistics. Rape Abus Incest Natl Netw. 2015. Reference Source

128. Cantor D, Fisher B, Chibnall S, et al.: Report on the AAU campus climate survey on sexual assault and sexual misconduct. Assoc Am Univ. 2015 Reference Source

129. Martin B: Countering supervisor exploitation. J Sch Publ. 2013; 45(1): 74-86. Publisher Full Text

130. No place for bullies in science. Nature. 2018; 559(7713): 151 PubMed Abstract | Publisher Full Text

131. Else H: Does science have a bullying problem? Nature. 2018; 563(7733): 616-8. PubMed Abstract | Publisher Full Text

132. Anonymous: Academia is built on exploitation. We must break this vicious cycle. The Guardian. 2018 Reference Source

133. Yamada S, Cappadocia MC, Pepler D: Workplace bullying in Canadian graduate psychology programs: Student perspectives of student-supervisor relationships. Train Educ Prof Psychol. 2014; 8(1): 58-67. Publisher Full Text

134. Frank E, Carrera JS, Stratton T, et al: Experiences of belittlement and harassment and their correlates among medical students in the United States: Longitudinal survey. BMJ. 2006; 333(7570): 682 . PubMed Abstract | Publisher Full Text | Free Full Text

135. Kokkinos $\mathrm{CM}$, Baltzidis $\mathrm{E}$, Xynogala D: Prevalence and personality correlates of Facebook bullying among university undergraduates. Comput Hum Behav. 2016; 55(Part B): 840-50 Publisher Full Text

136. Seguin E: Academic mobbing, or how to become campus tormentors. Univ Aff. 2016. Reference Source

137. Brooks R: Student-parents and higher education: A cross-national comparison J Ed Policy. 2012; 27(3): 423-39. Publisher Full Text

138. Powell K: Why scientist-mums in the United States need better parentalsupport policies. Nature. 2019; 569(7754): 149-51. PubMed Abstract | Publisher Full Text

139. Woolston C: Feeling overwhelmed by academia? You are not alone. Nat 
Careers. 2018; 557: 129-131.

Publisher Full Text

140. Powell K: Work-life balance: Break or burn out. Nature. 2017; 545: 375-377. Publisher Full Text

141. Woolston C: Psychology: Faking it. Nature. 2016; 529(7587): 555-7. PublMed Abstract | Publisher Full Text

142. Parkman A: The imposter phenomenon in higher education: incidence and impact. J High Educ Theory Pract. (Ohio Dominican University U. 2016; 16(1): $51-60$. Reference Source

143. Powell K: Should we steer clear of the winner-takes-all approach? Nature. 2018; 553(7688): 367-9. 553(7688): $367-9$.
PubMed Abstract | Publisher Full Text

144. Services UDSH and C: What is wellness? UC Davis. Reference Source

145. Global Wellness Institute: History of wellness. 2019. Reference Source

146. Oswald AJ, Proto E, Sgroi D: Happiness and productivity. J Labor Econ. 2015 33(4): 789-822. Publisher Full Tex

147. de Neve J, Diener E, Tay L, et al:: The objective benefits of subjective wellbeing. CEP Discuss Pap No 1236. 2013. Reference Source

148. Conley CS, Durlak JA, Dickson DA: An evaluative review of outcome research on universal mental health promotion and prevention programs for higher education students. J Am Coll Health. 2013; 61(5): 286-301. PubMed Abstract | Publisher Full Text

149. Conley CS, Travers LV, Bryant FB: Promoting psychosocial adjustment and stress management in first-year college students: The benefits of engagement in a psychosocial wellness seminar. J Am Coll Health. 2013; 61(2): 75-86. PubMed Abstract | Publisher Full Text

150. University of Illinois Counselling Centre: Suicide intervention policy. Univ Illinois Student Aff. 2015.

Reference Source

151. Fernandez A, Howse E, Rubio-Valera M, et al:: Setting-based interventions to promote mental health at the university: a systematic review. Int J Public Health. 2016; 61(7): 797-807.

PubMed Abstract | Publisher Full Text

152. Zheng G, Lan X, Li M, et al.: Effectiveness of Tai Chi on Physical and Psychological Health of College Students: Results of a Randomized Controlled Trial. PLoS One. 2015; 10(7): e0132605. PubMed Abstract | Publisher Full Text | Free Full Text

153. Caldwell KL, Bergman SM, Collier SR, et al:: Effects of tai chi chuan on anxiety and sleep quality in young adults: lessons from a randomized controlled feasibility study. Nat Sci Sleep. 2016; 8: 305-14. PubMed Abstract | Publisher Full Text | Free Full Text

154. Caldwell K, Harrison M, Adams M, et al.: Developing mindfulness in college students through movement-based courses: Effects on self-regulatory selfefficacy, mood, stress, and sleep quality. J Am Coll Health. 2010; 58(5): 433-42.

PubMed Abstract | Publisher Full Text | Free Full Text

155. Vidic Z, Cherup N: Mindfulness in classroom: effect of a mindfulness-based relaxation class on college students' stress, resilience, self- efficacy and perfectionism. Coll Stud J. 2019; 53(1): 130-144. Reference Source

156. Keng SL, Smoski MJ, Robins CJ: Effects of mindfulness on psychological health: A review of empirical studies. Clin Psych Rev. 2011; 31(6): 1041-56. PubMed Abstract | Publisher Full Text | Free Full Text

157. Bluth K, Campo RA, Pruteanu-Malinici S, et al:: A School-Based Mindfulness Pilot Study for Ethnically Diverse At-Risk Adolescents. Mindfulness (N Y). 2016; 7(1): 90-104. PubMed Abstract | Publisher Full Text | Free Full Text

158. Kuehner C, Huffziger S, Liebsch K: Rumination, distraction and mindful selffocus: Effects on mood, dysfunctional attitudes and cortisol stress response. Psychol Med. 2009; 39(2): 219-228. PubMed Abstract | Publisher Full Tex

159. Timm C, Rachota-Ubl B, Beddig T, et al:: Mindfulness-Based Attention Training Improves Cognitive and Affective Processes in Daily Life in Remitted Patients with Recurrent Depression: A Randomized Controlled Trial. Psychother Psychosom. 2018; 87(3): 184-6.

PubMed Abstract | Publisher Full Text 


\section{Open Peer Review}

\section{Current Peer Review Status:}

\section{Version 1}

Reviewer Report 04 May 2020

https://doi.org/10.5256/f1000research.23184.r62801

(C) 2020 Ackerson L. This is an open access peer review report distributed under the terms of the Creative Commons Attribution License, which permits unrestricted use, distribution, and reproduction in any medium, provided the original work is properly cited.

\section{Leland Ackerson}

Department of Public Health, University of Massachusetts at Lowell, Lowell, MA, USA

The Introduction of the article points to the 2007 recession as a key event regarding the financial concerns of today's students. I believe that updating this text to incorporate the Covid-19 related economic conditions will allow this article to remain relevant for a much longer time.

Some of the cited papers actually diagnosed patients with mental illness (such as depression or anxiety). Others were epidemiologic studies which relied on psychometric tools that provided evidence of symptomology but did not actually diagnose patients. It may be helpful to make this distinction in the current review when relevant. For example, the Garlow et al. paper (reference \#50) repeatedly refers to "depressive symptoms" while the relevant section of the current review (end of page 5 and beginning of page 6) refers to mild, moderate, and severe depression-not symptomology. I would encourage the authors to use language consistent with the referenced papers.

Both Liu et al. (reference \#111) and Kerr et al. (reference \#116) described sexual minorities as gay/lesbian. Yet on page 14 the authors used the term "homosexual" in the phrase "There is evidence that homosexual students experience poorer mental health and higher suicidality compared to heterosexual students ${ }^{111,116}$." This term is outdated and should be replaced in that paragraph and the following paragraph.

Is the topic of the review discussed comprehensively in the context of the current literature?

Yes

Are all factual statements correct and adequately supported by citations? Yes

Is the review written in accessible language?

Yes 
Are the conclusions drawn appropriate in the context of the current research literature? Yes

Competing Interests: No competing interests were disclosed.

Reviewer Expertise: Social Determinants of Health; Social Epidemiology; Intimate Partner Violence; Global Health; Mental Health.

I confirm that I have read this submission and believe that I have an appropriate level of expertise to confirm that it is of an acceptable scientific standard.

Reviewer Report 14 April 2020

https://doi.org/10.5256/f1000research.23184.r61928

(C) 2020 Evans T. This is an open access peer review report distributed under the terms of the Creative Commons Attribution License, which permits unrestricted use, distribution, and reproduction in any medium, provided the original work is properly cited.

\section{Teresa Evans}

Graduate School of Biomedical Sciences and Department of Pharmacology, UT Health Science Center San Antonio, San Antonio, TX, USA

Each topic is discussed comprehensively with well-rounded information provided on the impacts of mental health on undergraduate, graduate, and postdoctoral fellows. Clarification is provided to ensure confusion is not made between discussion of undergraduate data and graduate level data, particularly via tables. Further, the authors provide clear definitions of Depression, Anxiety, and Wellness along with a discussion of the scales used to assess symptomatology. Discussion of challenges faced by graduate students and postdoctoral fellows is comprehensive and well referenced. It is also important to note that the authors provide a strong overview of the data present for medical and health students as well.

All statements provided are factual and supported by citations. The review is well written and accessible. Also, all conclusions drawn are appropriate for the literature cited and the state of the field.

Is the topic of the review discussed comprehensively in the context of the current literature?

Yes

Are all factual statements correct and adequately supported by citations?

Yes

Is the review written in accessible language?

Yes 
Are the conclusions drawn appropriate in the context of the current research literature? Yes

Competing Interests: No competing interests were disclosed.

Reviewer Expertise: Graduate trainee mental health, K-12 STEM education, neuroscience.

I confirm that I have read this submission and believe that I have an appropriate level of expertise to confirm that it is of an acceptable scientific standard.

The benefits of publishing with F1000Research:

- Your article is published within days, with no editorial bias

- You can publish traditional articles, null/negative results, case reports, data notes and more

- The peer review process is transparent and collaborative

- Your article is indexed in PubMed after passing peer review

- Dedicated customer support at every stage

For pre-submission enquiries, contact research@f1000.com 